\title{
Aktibazioa eta gizarteratzeko eskubidea, EAE-ko enpleguko eta diru-sarrerak bermatzeko politiken esparruan
}

\section{SIIS Dokumentazio eta Ikerketa Zentroa}

Eguía-Careaga Fundazioa

<estudios@siis.net>

EAEko testuinguruan aktibazio-politikek izan beharko lituzketen oinarri teorikoak eta testuinguru horretan aktibazio-eredu inklusiboak izan behar lituzkeen ezaugarriak planteatzen dira artikulu honetan. Artikulua SIIS Dokumentazio eta Ikerketa Zentroak Eusko Jaurlaritzako Enplegu eta Gizarte Sailarentzat egindako txosten luzeago baten laburpena da. Txostenaren helburua da gogoetarako hainbat lerro teoriko proposatzea aktibazio-kontzeptua diru-sarrerak bermatzeko eta enpleguko politiken kudeaketan ezartzeko, batez ere Lanbideren esku hartzeko ereduaren esparru kontzeptuala eta filosofikoa izan dadin

\section{HITZ-GAKOAK:}

gizarte-bazterketa, enplegurako politika aktiboak, diruz emandako prestazioak, gutxiengo errentak bermatzeko sarea, gizarteratzeko programak.
En este artículo se plantean las bases teóricas en las que deberían sustentarse en el contexto de la CAPV las políticas de activación y las características que debería tener en ese contexto un modelo inclusivo de activación. El artículo resume un trabajo más amplio realizado por el SIIS Centro de Documentación y Estudios, a instancias del Departamento de Empleo y Asuntos Sociales del Gobierno Vasco. El objetivo del informe es el de proponer una serie de líneas de reflexión, de carácter teórico, sobre la aplicación del concepto de activación a la gestión de las políticas de garantía de ingresos y de empleo, que sirvan de marco conceptual y filosófico al modelo de intervención de Lanbide.

\section{PALABRAS CLAVE:}

exclusión social, política activa de empleo, prestaciones económicas, renta de garantía de ingresos, programas de inserción. 


\section{Sarrera}

2012ko urtarrilaren 1ean indarrean hasi ziren legegintza-aldaketen arabera, Lanbide Euskal Enplegu Zerbitzuak bere gain hartu du diru-sarrerak bermatzeko errentaren eta etxebizitza-osagarriaren kudeaketa, baita gizarteratze aktiboko hitzarmenen harpidetzaren eta jarraipenaren gaineko erantzukizuna ere.

Azken hilabeteetan, Eusko Jaurlaritzaren Enplegu eta Gizarte Gaietako Sailak kontzeptuzko eta antolamenduzko esparru bat garatu du legegintza-aldaketa horrek berekin dakarren erronkari erantzun egokia emateko. Ildo horretan, 2011n Plangintza eta Enplegu Sailburuordetzak gizarteratzeko eskubideari eta aktibazioari buruzko txostena ${ }^{1}$ egiteko bultzada eman zuen, EAEko diru-sarrerak bermatzeko eta enplegua sustatzeko politiken esparruan. SIIS Eguía Careaga Fundazioaren Dokumentazio eta Ikerketa Zentroak egindako txosten horren bitartez, zenbait gogoetaildo teoriko proposatu nahi ziren diru-sarrerak bermatzeko eta enplegua sustatzeko politiken kudeaketaren aktibazio-kontzeptuaren aplikazioari dagokionez, Lanbideren esku-hartze ereduaren kontzeptuzko esparru filosofiko gisa erabili ahal izateko.

Dokumentua urriaren 2oan aurkeztu zen jendaurrean, Gasteizen antolatutako jardunaldi batzuen esparruan. Aktibazioaren paradigmaren esanahia gainbegiratzen du dokumentu berriak. Gainera, dirusarrerak bermatzeko euskal sistemaren garapenean paradigma hori historian zehar zenbateraino egon den indarrean aztertzen du, eta, batez ere, eredu zehatz bat proposatzen du, kontzeptuzko oinarri filosofiko batzuetatik abiatuta. Eusko Jaurlaritzaren Enplegu eta Gizarte Gaietako Sailak ez du dokumentu horretan jasotako guzti-guztia ontzat hartzen, baina nolanahi ere dokumentu horretan planteatutako proposamena oinarri teoriko egokia izan daitekeela uste du, eta, hortik abiatuta, Euskal Enplegu Zerbitzuaren jardun-esparrua zehaztu litekeela, diru-sarrerak bermatzeko errentaren kudeaketari eta onuradunen gizarteratze aktiboari dagokienez.

Artikulu honen bitartez txosten hura laburtu nahi izan dugu, antzeko egitura bati eutsiz. Lehen zatian, aktibazioaren paradigma zehatz-mehatz deskribatu dugu, eskuragarri dagoen zientzia-literaturaren azterketatik abiatuta. Deskribapen horretatik abiatuta, bigarren zatiak gizarteratze aktiboko eredu bat proposatu du EAErentzat, herritar guztien eskubideak errespetatu nahi dituena funtsezko zenbait kontzeptutatik abiatuta, hala nola eskubide bikoitza, bidezko elkarrekikotasuna edo enplegagarritasun zabala.

${ }^{1}$ Txosten osoa ondoko helbidean kontsulta daiteke: [<http:// www.siis.net/documentos/ficha/197806.pdf)].

\section{Aktibazioaren paradigma}

\subsection{Gizarte-politiken aktibazioa: definizioa eta oinarrizko kontzeptuak}

Gutxienez azken 20 urteetan, mendebaldeko herrialdeetako gizarte-politiketan zenbait aldaketa nabari dira, guztiak ere aktibazioaren paradigma orokorraren barnean har daitezkeenak, nahiz eta, aurrerago ikusiko dugunez, paradigma horren barruan oso askotariko neurri eta politikak biltzen diren, oso helburu desberdinei erantzuten dietenak. Aditu guztiak ez dira bat etorri aktibazioaren kontzeptua zehazterakoan (Moreira, 2008), baina honako definizio hau onartua dago oro har: politika, neurri eta tresna multzoa, prestazio ekonomikoak jasotzen dituzten langabeak lan-merkatuan integratzeko eta horrela haien gizarte- eta ekonomia-integrazioko mailak hobetzeko abian jartzen direnak. Aktibazioaren paradigma oinarrizko zenbait printzipiotan oinarritzen da. Morenok eta Serrano Pascualek (2007) funtsezko hiru alderdi aipatu dituzte:

- Indibidualizazioa. Egile horien ustetan, paradigma berriak "norbanakoaren jokabide, motibazio eta jarreretan esku hartu nahi du, aberastasunaren bidezko birbanaketarako baldintza politiko egokiak ezarri baino gehiago. Aktibazio-politikek gero eta pertsonalizazio handiagoa sustatzen dute esku-hartzeetan, eta parte-hartze handiagoa eskatzen dute eraginpean hartutako pertsonaren aldetik. Norbanakoa da erreferentzia arau-emaile zein legitimatzailea”.

- Enpleguari lehentasuna ematea. Enpleguaren bitartez parte-hartze eta autonomia ekonomikoa sustatzea da politika horien helburua. Norbanakoak lan-merkatuaren aurrean ageri dituen portaeretan esku hartu nahi dute politika horiek, norbanakoa sustatuz, konbentzituz eta motibatuz. Hortaz, dimentsio ekonomikoei garrantzi handiagoa ematen die dimentsio politika eta sozialei baino gehiago, herritartasuna gauzatzean.

- Kontraktualizazioaren printzipioa. Serranoren eta Morenoren arabera, "kontratua metafora nuklear bihurtu da politika horien orientazioan eta legitimazioan. Baina horrek eskatzen du, halaber, herritartasun-kontzeptua betidanik eratu duen kontratu soziala aldatzea. Kontratuari balio morala ematen zaio balio politiko edo soziala baino gehiago: herritarrek, beren eskubideak jasotzeko, baldintza jakin batzuk bete behar dituzte, eta beren parte-hartze ekonomikoari dagokionez hartzen duten jarreraren eta portaeraren araberakoak izango dira eskubide horiek. Kontratua jaun eta jabe da gizarte-erregulazioko mekanismo gisa, eta, horrekin batera, 'elkarrekikotasun-araua' berresten da, 'merezimendua' funtsezko ardatz bihurtuz herritartasunaren legitimitatean”.

Azkenik, egile horiek honako hau adierazi dute:
Aktibazioaren paradigmak lan-merkatuan esku hartzea eskatzen du, baina esku-hartze soil 
horretatik haratago doa. Langabeziaren, prestakuntzaren edo gizarte-bazterkeriaren arazoen diagnostikoaren birdefinizioa eskatzen du, baita ongizatearen estatuaren, soldatakoen eta enplegu-emaileen artean erantzukizunak berriz antolatzeko abian jar daitezkeen alternatiba legitimoen birdefinizioa ere. Azken batean, hirugarren milurtekoaren hasieran, Europako gizarte-gaiak antolatzeko erabili ohi diren ardatz sozial eta moralak eraldatzeko prozesua planteatzen du aktibazioaren paradigmak.

\subsection{Paradigma berri bat? Zenbait aurrekari historiko}

Harritzekoa da, nolanahi ere, zenbait egilek behin eta berriz esatea aktibazio-kontzeptua elementu berria dela gizarte-politikak zehaztean. Pérez Eransusek adierazi duenez (2005), laguntzaren eta enpleguaren arteko harremana ez da berria, eta lan egiteko gaitasunik ez duten pobreei lagundu beharra gizartelaguntzaren garapenaren funts nagusietako bat izan da, hasiera-hasieratik. Izan ere, lanaren balioa eta norbanakoaren erantzukizuna aldarrikatzea gizartepolitiken historian oso sustraituta dauden ereduen ondorio da, eta pentsatzekoa da aktibazio-politikek ongizate-erregimen jakin batzuekiko haustura baino ez luketela ekarriko, hain zuzen ere, oso testuinguru geografiko eta historiko mugatu batean, diru-sarrerak bermatzeko garrantzi handiko sistema unibertsala ezarri zuten ongizate-erregimenekiko haustura.

Nolanahi ere, politika horiek abian jartzeko prozesuari buruzko analisi historikoaren arabera, gutxienez hiru iturri ideologiko nagusi bereiz ditzakegu, batzuetan kontrajarriak direnak eta beste batzuetan gainjartzen direnak, eta horiei dagokie ikuspegi hori orokortzeko lidertza politikoa:

- Iraultza kontserbadorea 8oko hamarkadan. Estatu Batuetan, 6oko hamarkadatik ezarri zituzten aktibazioaren filosofiarekin bat zetozen neurriak, baina neurri horiek bereziki garatu ziren Erresuma Batuan Margaret Thatcher eta Estatu Batuetan Ronald Reagan (1979an eta 1980an, hurrenez hurren) boterera iritsi ziren uneaz geroztik. Gizartean nahikoa hedatua zegoen pertzepzio baten arabera, gizarte-laguntzak jasotzen zituztenen artean hainbat kronifikazio- eta mendetasunegoera gertatzen ari ziren, eta onuradunen sektore bat parasitismoan erortzeko arriskua zegoen (bestetik aipatzekoa da hori ez dela berria gizarte-politiken historian, laguntza merezi duten eta merezi ez duten -deserving and undeserving poors- pobreen arteko bereizketa dakarrelako gogora). Gainera, buruzagi horiek norbanakoaren erantzukizunaren eta lanaren etikaren ohiko printzipioak birformulatu zituzten, ikuspegi zorrotzago bati jarraiki.

- Hirugarren bidea 9oeko hamarkadan. Politikaeremuan, nolanahi ere, aldaketa horren benetako indar sustatzailea zentro-ezkerreko alderdi anglosaxoien eskutik etorri zen, eta, oso bereziki, Tony Blairen Alderdi Laboristaren eskutik, Anthony
Giddensen postulatu ideologikoen babesean, eta Bill Clintonen Alderdi Demokrataren eskutik, besteak beste Lawrence Meaden pentsamolde neopaternalistaren eragin nabaria zuena. Ezbairik gabe, bi politikari horien agintearen eta eraginaren mendean (pixka bat geroago, Schroeder sozialdemokrata alemana atxiki zitzaien) hartu ziren gizarte-politikak aktibatzeko neurri nagusiak, hala nola Personal Responsability and Work Opportunity Act 1996an Estatu Batuetan, edo New Deal programa sorta, 1997az geroztik Erresuma Batuan garatu zena, hurrenez hurren: 'Lana lan egin dezaketenentzat eta segurtasuna ezin dutenentzat' izan zen administrazio laboristak eremu horretan erabili zuen goiburu nagusia. Laboristek liburu berdea argitaratu zuten, boterera iritsi ondoren urtebete igarotakoan, eta, liburu horren arabera, "Gobernuak Ongizatearen Estatua berreraiki nahi zuen, lanaren inguruan”, enplegu-politika aktiboak, laguntza-zerbitzuak eta zerga-murrizketak ezarriz, eta "eskubide eta erantzukizunen arteko oreka egokia bermatuz”.

- Nazioarteko erakundeak, eta bereziki, ELGA eta Europar Batasuna. Arribak eta Pérez Eransusek adierazi dutenez (2007), “lan-merkatuko politika aktiboak laurogeiko hamarkadan hedatu ziren nazioarteko erakundeen eskutik, hala nola NBE, ELGA, Nazioarteko Bankua, eta 9oeko hamarkadaren erdialdetik, Europar Batasuna. Une hartan kezka zen nagusi egiturazko langabezia zela medio, eta nazioarteko erakunde horiek Estatuei langabeen prestakuntza-maila hobetzeko neurriak abian jartzeko gomendatu zieten, langabe horiek eszenatoki lehiakor berriaren premietara egokitzeko aukera izan zezaten. Estatuei zera proposatu zitzaien, babes ekonomikoko politiken ordez (une hartatik aurrera pasiboak deitu zieten) langabeak berriz laneratzea sustatzeko neurri edo politika aktiboak abian jartzea”. EBk guztiz bat egin du eredu berriarekin -izan ere, hainbat egileren aburuz, neurri horiek abian jartzean erkidegoaren lidertza erabakigarria izan da ereduaren ezaugarriak zehaztean- ekiteko eta aktibazioaren alde egiteko gomendioetan, eta eredu hori eta mendetasunarekiko kezka Nizako Itunaz geroztik bultzatutako Gizarteratze Plan Nazionaletara eraman dira berehala.

Nolanahi ere ez dugu pentsatu behar aktibazioneurriak herrialde anglosaxoietara edo nazioarteko erakundeen eraginera mugatu direnik. Batetik, Escandinaviako herrialdeek gizarte-politikak aktibatzeko hainbat neurri jarri zituzten abian 8oko hamarkadatik aurrera, herrialde horietako enplegupolitika aktiboen garapen zabalarekin bat etorriz. Suedian, esaterako, 1998ko Gizarte Zerbitzuei buruzko Lege berriaren arabera, 20 urtetik gorako pertsonek gizarte-laguntza jasotzeko eskubidea dute, baina betiere lan- eta prestakuntza-jardueretan parte hartzen badute. Ildo beretik, 9oeko hamarkadan Danimarkak zenbait lege aldatu zituen aktibaziorako eskubidea eta betebeharra onartzeko. Besteak beste, arrazoizkotzat jotako lanpostuetan lan egiteko edo 
prestakuntza-jardueretan parte hartzeko betebeharra ezarri zuten (Moreira, 2008).

Bestetik, Frantziak -eta, aurrerago adieraziko dugunez, Espainiako autonomia-erkidego gehienek, EAE buruan- gizarteratzeko gutxieneko errentetan oinarritutako sistema bat ezarri zuten 8oko hamarkadaren amaieran, neurri handi batean aktibazioaren printzipioekin bat datorrena, eta, ikuspegi teorikotik behintzat, baldintzazkotasun-kontzeptu zorrotza ezarri duena. Frantziako ereduak badu beste zenbait bereizgarri gainerako aktibazio-formulen aldean. Esaterako, gizarteratzea laneratze soiletik haratago doala hartzen du aintzat, bazterkeria kausa anitzeko fenomenoa dela kontuan hartuta. Gainera, oreka handiagoa bilatzen du norbanakoaren erantzukizunaren eta erantzukizun kolektiboaren artean, bazterkeriaprozesuak interpretatzean eta horri dagokionez aplikatu beharreko politikak zehaztean.

\section{EAE-n gizarteratze aktiboko eredua zehazteko oinarrizko ildoak}

\subsection{Eredu berria zehazteko oinarrizko kontzeptuzko osagaiak: gizarteratze aktiboa diru-sarrerarik ez duten langabeen eskubide eta betebehar gisa}

Aurreko orrietan aktibazioaren paradigmari dagokionez egin dugun gainbegiratze ezinbestean partzialak aukera eman digu gure inguruko herrialdeetan aktibazio-eredu bat baino gehiago daudela ezartzeko, eta eredu horiek desberdinak direla, eta, erakunde-tradizio eta ikusmolde ideologiko desberdinen ondorio izanik, emaitza halaber desberdinak eman dituztenak, politika horiek herritarrengan eta zehazki langabe edota baliabiderik ez dutenengan duten eraginari eta emaitzei dagokienez.

Izan ere, Morenoren eta Serranoren ustetan (2009), aktibazioaren eredu berria ulertzean aurkako bi interpretazio nabari dira, batetik arauzko eta elkartasunezko printzipioak indartu nahi dituena, eta, bestetik indibidualizazioa indartzearen eta herritarren ongizatearen birmerkantilizazioaren alde egin nahi duena, eta horri jarraiki, Europako herrialdeek bateko edo besteko aktibazio-paradigmak sortu dituzte. Hala, batzuek "herritartasuna gauzatzeko baldintzak indartu" nahi izan dituzte, eta beste batzuek, aldiz, "ekonomia-lehiakortasunaren aldeko apustua egin dute, langilearen kondizio politikoari eta sozialari muzin eginez". Egile horiek diotenez, aktibazioaren kontzeptua ulertzeko zenbait modu egonik, aplikazio zehatzak ere anitzak dira, eta, hori hala izanik, oso bestelako politikak sortzen dira, herrialde bakoitzean nagusi den erakunde-konfigurazioaren arabera.

Hortaz, diru-sarrerak bermatzeko politiken eta enplegu-politiken arteko lotura etikoki justifikagarriak diren oinarrietatik zehazterakoan, funtsezkoa ez da aktibazioaren paradigma onartu behar den edo ez, baizik eta zehazki zer aktibazio-eredu aplikatu nahi den, zer ikusmolde teorikotatik eta zer oinarri filosofikotatik garatu nahi den zehaztea, eta, zehaz- kiago, aplikazioak oinarrizko zer osagai bildu behar dituen erabakitzea. Hau da, egungo zirkunstantzietan EAEn gizarteratze- aktiboko eredu bat nola antola litekeen zehaztea da kontua, aipatu berri ditugun egileek diotenez, herritartasuna gauzatzeko baldintzak indartzeaz gain gizabanakoaren emantzipaziorako eta trebakuntzarako tresna bihurtuko dena.

Aktibazioak, edo gutxienez aktibazioaren zenbait aplikaziok, hainbat kritika jaso dituzte, baina kritika horiei erantzunez, lehenik eta behin, paradigma horretan oinarritutako eredu baten aplikazioa sustatzera eraman duten arrazoiak justifikatu beharko lirateke. Zerk eraman du aktibazioaren paradigma, oro har behintzat, babestera? Lehenik eta behin, eta funtsezko argudioa hori ez bada ere, aipatzekoa da paradigmaren hedapena ia unibertsala dela, eta gure inguruko ia herrialde guztietan onartua dagoela, baita gizarte-politika aurrerakoienak garatu dituztenetan ere. EAEren ikuspegitik, halaber, aipatzekoa da, batetik, hasiera-hasieratik kontzeptu hori onartu egin zela gutxieneko errentei buruzko euskal politiketan, eta, bestetik, indarreko araudian jasotako lege-aginduak aktibazio-kontzeptuaren eta enpleguari lehentasuna ematearen aldeko apustu argia egin nahi duela gizarteratzeko tresna den heinean, eskubide bikoitzaren kontzeptutik abiatuta.

Nolanahi ere, funtsezko arrazoiek kontzeptuzko alderdiekin dute zerikusia:

- Lehenik eta behin azpimarratzekoa da, lan merkatua gaur egun egoera ezegonkorrean egonik ere, okupazioa, eta, zehazki, ordaindutako enplegua, gizarteratzeko, norberaren errealizaziorako eta pobreziaren aurka babesteko funtsezko mekanismoak direla. Ikuspegi horretatik, enplegurik ez dutelako (edo enpleguak behar adinako diru-sarrera ematen ez dizkielako) gutxieneko diru-sarrerak ez dituztenei enplegagarritasuna hobetzeko eta laneratzea sustatzeko tresna lagungarriak eskaintzeak gizarterazte-politika ororen oinarrizko helburua izan behar du, eta, horri jarraiki, gizabanakoari eskubide bat eskaini behar zaio, hain zuzen ere laneratzearen bitartez gizarteratzeko eskubidea.

- Aktibazio-kontzeptua justifikatzen duen bigarren arrazoiak diru-sarrerak bermatzeko prestazioen onuradunen erantzukizun, betekizun edo betebehar pertsonalarekin du zerikusia. Whitek adierazi duenez (2000), eta hurrengo orrietan zehatz-mehatz jaso denez, diru-sarrerak bermatzeko eskubidea gizabanakoaren autonomiaren interpretazio etiko batean oinarritzen da, eta, horren arabera, pertsonek, ahal dela behintzat, ez dute beren herritarrentzako zama izan behar, hori esplotazio modu bat litzatekeelako, eta, arrazoi berberengatik, besteek komunitateari eusteko egiten duten ahaleginari erantzunez, guztion ongizatea eraikitzeko ekarpena egin behar dute, bakoitzak ahal duen neurrian. Izan ere, T.H. Marshallek bere garaian esan zuenez, "herritarren eskubideak babestu behar dira, baina herritarrek betebehar batzuk ere badituztela ahaztu gabe". 
Hortaz, aktibazio-kontzeptua pertsonen eta oro har gizartearen eskubide eta erantzukizunen logikari lotzen zaio. Horrek aktibazio-eredu inklusibo bat aplikatzea eskatzen du, bidezko elkarrekikotasun-kontzeptuan oinarritua, gizabanakoaren erantzukizunaren eskakizuna legez planteatzeko aukera ematen duena.

- Bestetik, aktibazioaren paradigmari merkantilizatzailea izan daitekeela leporatu ohi zaio, baina ez dugu ahaztu behar beste zerbitzu publiko batzuk ez bezala, gizarte-babesaren eremuko zerbitzuak eta prestazioak, eta bereziki diru-sarrerak bermatzeko prestazioak, prestazio horien premia egiaztatzen dutenei ematen zaiela, banan-banan, edo premia-egoera esleitu ohi zaion kolektibo bateko kide izateagatik. Beste baldintza osagarri batzuk ezarri edo ez, argi dagoena da ez jardutearen aldeko erabaki indibiduala ez datorrela nahitaez premia-egoera batetik, eta, nolanahi ere, lanean ari ez direlako premia ekonomikoa duten pertsonek egoera horretatik irteten ahalegintzeko sen onari jarraiki beharrezkoak diren bitartekoak jarri behar dituztela.

Ikuspegi horretatik, gizarteratze aktiboak gizarteeskubideekin zein erantzukizun, betekizun edo betebehar indibidualekin du zerikusia:

- Eskubide bikoitzaren logikan, gizarteratze aktiboari esker, langabeek guztiz gizarteratzeko beharrezko laguntzak jasotzeko eskubidea bete dezakete, eta, zehazkiago, enplegagarritasuna hobetzeko eta lan-merkatuan benetan txertatzeko tresnak jaso ditzakete. Hortaz gizabanakoaren eskubidea gauzatu behar da, prestazio ekonomikoaren eskubideaz aparte, eta horretarako erakundeek enplegagarritasuna sustatzeko konpromisoa hartu behar dute, enplegagarritasuna ikuspegi zabal baten arabera ulerturik. Orain artean prestazioak arlo ekonomikora mugatu dira sarri, baina horrek ez du berez, inondik inora, gizarteratzea bermatzen. Eskubide bikoitz hori hautatzeak, ordea, erakundeei programa eta zerbitzu jakin batzuk abian jartzea eskatzen die, honako xede hauetarako: a) langabeei laguntzea gizarteratze- eta laneratze-prozesuan; b) langabeen enplegagarritasun-mailak hobetzea, trebetasun jakin batzuk eskatzen dituen lanmerkatuan sartzeko erraztasunak emanez; eta d) lan-merkatuaren baldintzetan eta enplegu-eskari erantsian esku hartzea, enpleguak integratzeko duen gaitasunaren galera saihesteko sen onari jarraiki jar daitezkeen bitarteko guztiak jarriz.

- Aurrerago aipatuko dugun bidezko elkarrekikotasunaren logikatik begiratuta, gizarteratze aktiboa betekizun edo betebehar pertsonala ere bada, legezkoa delako gizarteak zenbait eskakizun jartzea prestazioen hartzaile diren langabeentzat: a) ahalegin pertsonal bat, dauden premia-egoeratik ateratzeko; eta b) produkzio-ekarpen bat gizartearen funtzionamendu egokia bermatzeko. Nolanahi ere, ekarpen hori ez da kontraprestazio edo kontrapartida bat, jasotako zerbitzuengatiko ordainketa bat edo zor baten itzulketa ez den heinean, gizartearen funtzionamenduari egindako ekarpena baizik ${ }^{2}$, eta, bestetik, erakundeei baldintza batzuk betetzea eskatzen die, bereziki enpleguaren kalitateari eta lan-merkatuaren baldintzen gaineko esku-hartze publikoari dagokienez, ekarpena legez eskatzeko modukoa izan dadin.

Eskubide bikoitzaren eta gizabanakoaren erantzukizunaren kontzeptuak uztartzeak aukera ematen du gure gizarteetan diru-sarrerak bermatzeko politiken oinarri den gizarte-kontratuaren interpretazio egokiago bat egiteko. Eskubide bikoitzaren kontzeptuari bakarrik erreparatzea, ez badugu kontzeptu hori nahitaezko eskubide baten logikatik aplikatu nahi $^{3}$, ez dator bat diru-sarrerak bermatzeko politiken azpiko esparru teorikoarekin; izan ere, horren arabera hartzaileek ezin dute jardun gabe jarraitu, egoera hori saihestea haien esku badago behintzat. Azken batean laguntza jakin batzuk jasotzeko eskubideari uko egiteko aukera badute, baina zenbait konpromiso eta erantzukizun bete behar dituzte nahitaez, diru-sarrerak bermatzeko prestazioa jasotzearen azpian dagoen elkarrekikotasunkontzeptuari zein herritartasuna ulertzeko moduari berari dagozkien heinean. Gizarteratze aktiboa gizarte-eskubideak zabaltzean oinarritzen duen eredua justifikatzen da, halaber, prestazioen hartzaileek normalean enplegua eskuratzeko laguntzak nahiago izaten dituztelako baldintzarik gabeko prestazio ekonomiko bat jasotzeko eskubidea baino gehiago.

Hortaz, EAEn gizarteratzeko aktibazio-eredu bat defendatzeko behar adinako arrazoiak badaudelako ondorioa atera dezakegu, eta arrazoi horiek, funtsean, euskal erakundeetako arduradunek ezarritako kontzeptuzko ildo ideologikoekin -eta, areago oraindik, EAEko diru-sarrerak bermatzearen arloan indarrean dagoen araudian jasotako gizarteratzeereduarekin- bat datozela ere ondoriozta dezakegu.

Hala eta guztiz ere, eta aldez aurretik adierazi dugunez, zehaztu gabeko aktibazio-ikusmolde bat aldarrikatzeak ez du inolako zentzurik; ezaugarri espezifiko eta zehatz batzuk dituen eredu baten aldeko apustua egin behar da, argi eta garbi. Aurreko orrietan egindako analisiaren arabera, zein dira eredu horren oinarrizko ezaugarriak? Funtsean, hiru izan daitezke:

- Eskubide bikoitzaren printzipioa. Dokumentu honetan proposatzen dugun eredua, aldez aurretik adierazi dugun bezala, 18/2008 Legeak

2 Pertsona horiei gizartearen funtzionamenduari ekarpen bat egiteko eskakizuna bera inklusiboa da, eta ekarpen-betebehar hori aparte uztea, ordea, baztertzeko arrazoia da, Gorzek bere garaian adierazi zuen bezala.

${ }^{3}$ Nolanahi ere ez dugu ahaztu behar Espainiako Konstituzioaren 35. artikuluak honela dioela: "Espainiar guztiek lan egiteko eginbeharra dute, eta lanerako eskubidea dute, lanbide edo ogibidea as katasunez aukeratzeko eta lanean igotzeko eskubideak dituzte, eta beren beharrizanak eta beren familiarenak asetzeko adina ordainsari jasotzeko eskubidea ere, inoiz sexu-arrazoiengatik bereizkeriarik gertatu gabe". 
onartzen duen eskubide bikoitzaren kontzeptuan sakontzean oinarritzen da. Eskubide bikoitzaren kontzeptuak honako bi eskubide osagarri hauek onartzea eskatzen du:

a. Batetik, lanik edota baliabide ekonomikorik ez duten pertsonek administrazio publikoetatik gizarteratzeko behar dituzten laguntzak jasotzeko eskubidea dute. Egia bada ere printzipio hori hasiera-hasieratik jaso zela errentak bermatzeko euskal ereduan, beste herrialde batzuetan gertatu den bezala gurean ere ezer gutxi hedatu dela esan dezakegu, eta sarritan, askotariko arrazoiak direla medio, pertsona horiek jasotako laguntza bakarra prestazio ekonomikoa izan dela, gizarte- eta lan-arloetako laguntzak bereziki nabarmendu ez direla. Hortaz, dokumentu honetan proposatzen dugun gizarteratze-aktiboko ereduaren oinarrizko osagaietako baten arabera, laguntza horiek areagotu egin behar dira, eta bereziki, lanik ez duten edo gizartean integratzeko maila egokiak bermatzeko moduko lana ez duten pertsonen enplegagarritasuna hobetzearekin zerikusia dutenak. Gainera, proposatzen dugun helburuak enplegagarritasunaren ikusmolde zabala sustatu nahi du, gizabanakoaren gaitasun eta betebeharrei ez ezik gizarte- edo egitura-arlokoei ere helduko diena, baita giza kapitalaren garapena eta laneratze iraunkorren bilaketa jomugan izango dituen esku-hartze eredua sustatu ere.

b. Bestetik, diru-sarrerak bermatzeko prestazioak jasotzen dituzten hainbat pertsonak premia ekonomikoak baino ez dituzte, eta, hortaz, gizarteratzeko edo laneratzeko laguntzapremiarik ez dute. Ildo horretan, diru-sarrerak bermatzeko politika egokiak ezarri beharko lirateke, diru-sarrerei dagokienez egoera eta familia jakin baterako nahikoa ez den maila osatzera mugatuz, eta horretarako, aurrerago azalduko dugunez hobekuntza eta aldaketa jakin batzuk erantsi beharko lirateke prestazioaren kudeaketa bizkortu eta automatizatzeko.

- Gizarteratze-printzipioa. Dokumentu honetan jasotako proposamenak honako ideia hau hartu du oinarritzat: gizarte-politika publikoek, eta horien barnean enplegu-politikek, gizarteratzeari eman behar diote lehentasuna. Kontzeptua oraindik behar bezala zehaztu ez bada ere, kontzeptuaren oinarrizko osagaietako bik funtsezko eragina dute aktibazio-politiken edukia zehaztean:

a. Ezinbestean, bazterkeriaren kausa-aniztasuna onartzeak gizarteratzearen dimentsio-aniztasuna eskatzea dakar, hau da, gizabanakoaren premia eta egoeren arabera, gizarteratzea laneratzetik bakarrik ez, baizik eta askotariko bizi-eremuetatik lor daitekeela onartzea. Nolanahi ere, azpimarratu beharra dago agian bakarra ez bada ere, enplegu arruntera biltzea gaur egun funtsezko baldintza dela lan egiteko adinean dauden pertsonek guztiz gizartera- tzeko aukera izan dezaten. Hala eta guztiz ere, gizarteratzearen atzean kausa anitz badaudela onartzeak aukera ematen du, batetik, gizartearentzat baliagarri diren jarduerei, eta ez soilik ordaindutako enpleguari, lotutako gizarteratze-prozesuak planteatzeko, eta, bestetik, laneratzea zenbaitetan lehentasunezko beste zenbait helburuen mendean jarri behar dela onartzeko, osasunari, harreman pertsonalei edo gizarte-funtzionamenduari dagokienez.

b. Gizarteratzearen paradigma gizarte-integrazioaren paradigmaren azpian daudenez bestelako oinarrietatik abiatzen da, eta ezgaitasunaren gizarte-ereduari lotzen zaio zuzenean. Eredu horrek integrazioa ulertzeko zenbait ikuspegi zalantzan jartzen ditu; izan, ere, besteak beste, honako printzipio honetatik abiatzen da: ezgaitasuna sorrarazten duten arrazoiak ez dira indibidualak, baizik eta, batez ere, sozialak. Arazoaren sustraiak ez dira gizabanakoaren mugetan bilatu behar, gizarteak zerbitzu egokiak emateko eta ezgaituen premiak gizarte-antolamenduaren barnean behar bezala kontuan har daitezela ziurtatzeko erakusten dituen mugetan baizik (Palacios eta Bariffi, 2007). Gogoeta hori pobreziaren mundura eraman dezakegu, honako ideia honetatik abiatuta: emandako zerbitzuek zein gizarteratze-prozesuen helburuek ezinbestean aldatu behar dira nagusi diren faktore sozioekonomikoetan, eta bereziki lan-merkatuan, pertsona guztien ezaugarrietara egokitu ahal izateko. Garrantzitsua da pertsonen ezaugarriak lan-merkatuaren premietara egokitzea, baina garrantzitsua da, halaber, lan-merkatuaren premiak pertsonen premietara egokitzea.

- Konpromiso bikoitzaren (edo bidezko elkarrekikotasunaren) printzipioa. Gizarteratzea lortzeko eskubide bikoitzaren kontzeptua konpromiso bikoitzari lotu behar zaio, ezinbestean: batetik, prestazioen onuradunek bizi duten premiaegoeratik ahal den neurrian irteteko konpromisoa hartzen dute, eta, bestetik, kolektibitateak, funtsean Administrazioaren ekintzaren bitartez, baina baita enpresen eta gizarte zibilaren bidez ere, lan-merkatu inklusiboa bermatzeko konpromisoa hartzen du, baita, Lanaren Nazioarteko Erakundeak babestutako 'lan duinaren' ideian oinarritutako bidezko lan-harremanak eta kalitatezko laguntza-zerbitzu indibidualizatuak bermatzeko konpromisoa ere. Funtsean, konpromiso bikoitzaren kontzeptua bidezko elkarrekikotasunaren nozioan oinarritzen da. Horren arabera, ontzat hartzen bada pertsonek erantzukizun jakin batzuk dauzkatela, eta erantzukizun horiek legez betearazteko agindua eman daitekeela baldintza batzuk ezarrita, orduan Estatuak ere bere erantzukizunak bete behar ditu, eta, bereziki, aukeraberdintasuna bermatu behar du.

Grafikoki, eskubide eta betebeharren esparruan oinarritutako aktibazio-eredu inklusiboa ezar dezakegu, eta, horren arabera, gizabanakoaren eskubideak 


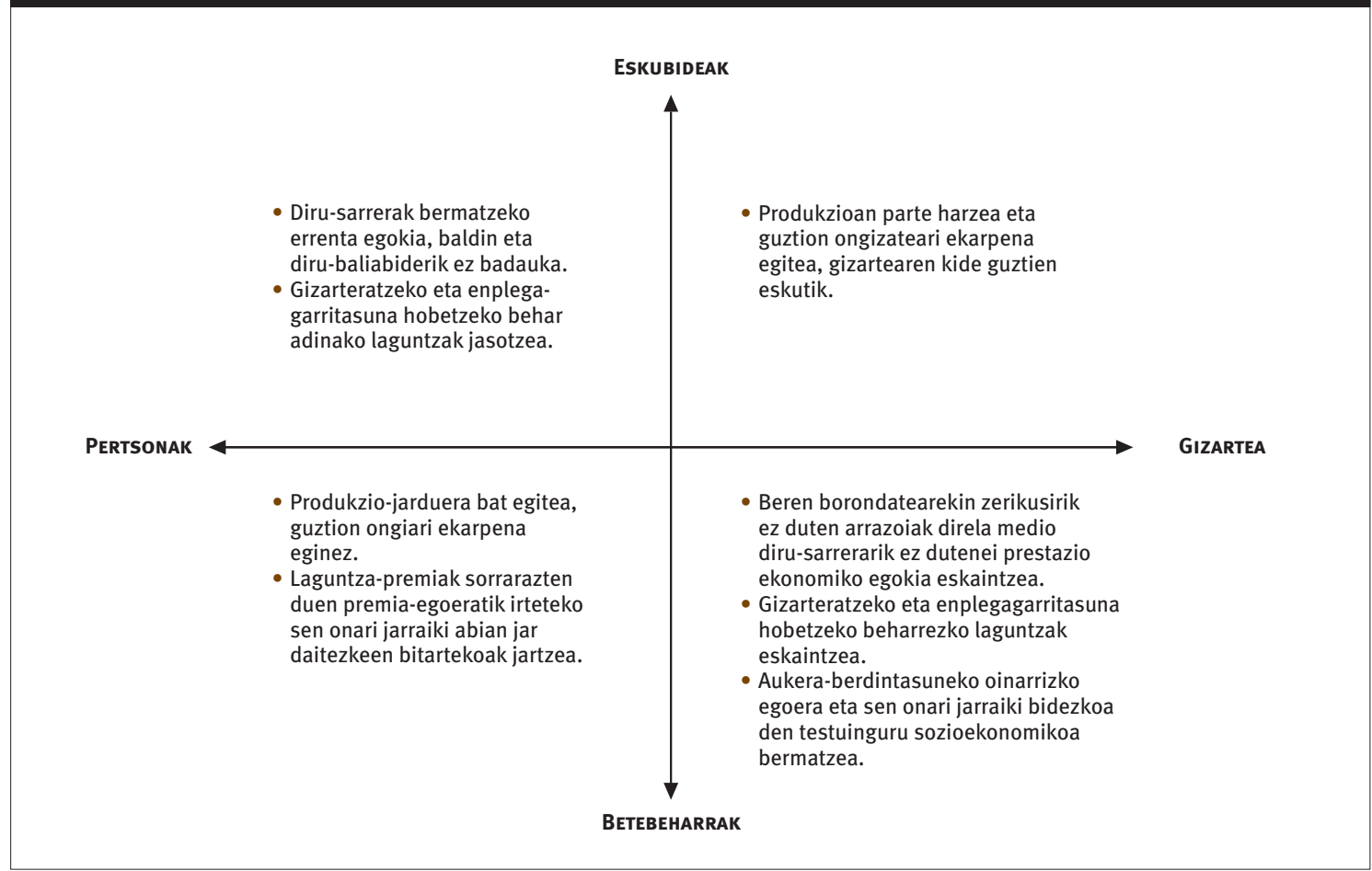

Iturria: Egileen lana.

bat etorriko lirateke gizartearen betebeharrekin, eta gizartearen betebeharrak, berriz, gizabanakoaren eskubideekin.

Hurrengo orrietan, aipatutako oinarrizko kontzeptuzko osagaietatik abiatuta, EAErako gizarteratze aktiboko ereduak bildu beharko lituzkeen ezaugarriak jaso ditugu, ikusi berri dugun eskeman oinarrituz.

\subsection{Eskubide bikoitzeko kontzeptuan oinarritutako diru-sarrerak bermatzeko eredu bat, enplegagarritasuna gizarte-eskubidea dela eta laneratzea gizarteratzearen oinarrizko osagaia dela aldarrikatzen duena}

\subsubsection{Enplegua gizarteratzeko eta pobreziatik babesteko mekanismo gisa, eta enpleguaren ahalmen gizarteratzailea lan-ezegonkortasuneko garaian}

Gaur egun prekarizazio-prozesuan murgilduta egonik ere, ordaindutako enplegua gizarteratzeko formula nagusia da oraindik ere. Izan ere, J. L. Retolazak Hilero Eguneratuz (2003) aldizkarian azaldu zuenez,

jasotako errentaren zenbatekoa edozein izanik ere, gizarteratzeari uko egiten dion edozein eredu ez da konponbidea, arazoa askoz ere sakonagoa delako diru-sarreren gabezia baino. Lana ez da diru-sarrera iturri soila, naturarekin eta gizartearekin harremanetan sartzeko oinarrizko bitartekoa ere bada, eta sakoneko ondorioak ditu pertsonaren prozesu kognitiboen garapenean. Arrazoizko lana eskubide bat da, ezinbesteko premia ukaezina. Ildo horretan, bazterkeriaren aurkako borrokak eraldaketa sozioekonomikoa eskatzen du eredu zabalago bat lortzeko, eta, eredu berriaren arabera, ekonomia, enpresak eta produkzioprozesuak pertsonen zerbitzuan egongo dira, kapitalaren mendean egon beharrean.

Ildo horretan, argi dago landunen egoerak langabeena baino hobea izaten jarraitzen duela, eta enpleguak pobreziaren aurka babesteko faktorea izateari eusten diola. Tohariaren eta beste batzuren ustetan (2008),

jarduera ekonomikoarekin zerikusia duten ezaugarri jakin batzuek, hala nola jardunean ez aritzeak, edo, bereziki, langabe egoteak, areagotu egiten dituzte gizabanakoek pobrezia erlatiboan edo pobrezia larrian egoteko dituzten aukerak. Gainera, une jakin bateko egoerak ez ezik, iraupenak ere garrantzi handia du, izan ere, aktiboak izanik enplegutik aparte denbora gehien ematen dutenek pobrezian erortzeko aukera gehiago dituzte.

Tohariaren arabera,

gizabanakoen eta etxekoen unitateen egoera ekonomikoari buruzko egoera haien bizi-baldintzekin (etxebizitza-arazoak, garrantzizko ordainketa jakin batzuetan berandutzea, erosketa jakin 
batzuk egiteko gabeziak) lotzean, errentari buruzko zeharkako adierazlearekin lortutakoaren antzeko emaitza lortzen dugu; ildo horretan, antza denez, lanarekiko lotura handiago batek bizibaldintza hobeak dakartza berekin.

Lanik gabe daudenen egoera ekonomikoa okerragoa da lana dutenena baino, eta, ezbairik gabe, horrek zerikusi handiagoa izan dezake langabeen edo ezaktiboen babesgabeziarekin enpleguaren gaitasun inklusiboarekin baino. Hala eta guztiz ere, ezin dugu alde batera utzi gaur egungo zirkunstantzietan, lana dutenek lanik ez dutenek baino maila handiagoak dituztela gizarteratzeari, ongizate ekonomikoari eta zoriontasunari edo bizi-gogobetetzeari dagokienez, eta, ikuspegi horretatik, laneratzeko estrategiak indartzea guztiz beharrezkoa dela. Ikuspegi horretatik, eta gizarteratzeko aktibazio-programak benetan eskubide bikoitzaren printzipioan oinarritzen badira, hau da, premia duten pertsona guztiei behar adinako prestazio ekonomikoa bermatzen bazaie eta lanmerkatuan txertatzeko modurik ez dutenen enplegagarritasuna hobetzeko eta gizarteratzeko beharrezko laguntzak jartzen badira, programa horiek abian jartzeak ez du inondik inora gizarte-eskubideen murrizketa ekarriko, eskubide horiek zabaltzea baizik.

Zehazki, gure inguruko beste herrialde batzuetan ikuspegi aurrerakoi batetik aktibazio-eredu inklusiboak garatzen ari diren erakundeen iritziz, enplegua lortzeko zailtasun handienak dituztenei gutxienez honako eskubide hauek bermatu behar zaizkie (McNeil, 2010):

- Laneratzeko oztopo indibidualei buruzko ebaluazio errealista egiteko eskubidea.

- Kalteberatasun-egoeran dauden pertsonei laguntzeko eskarmentua duten erakundeen arreta jasotzeko eskubidea.

- Pixkanakako plan indibidualizatu batean integratutako kalitatezko zerbitzuak jasotzeko eskubidea, enplegua lortzea eta trebetasun indibidualen hobekuntza oztopatzen duten trabei heltzeko.

Behar adinako lanbide-trebakuntza duten orientatzaileen aldizkako laguntza jasotzeko eskubidea.

Metamorfosis del trabajo (Lanaren metamorfosia, 1995) lanean, Gorzek argi eta garbi adierazi du lan arrunta oso garrantzitsua dela gizarteratzeko osagai gisa: “Edo gizarteko kide gara (zehazkiago, esklabista ez den gizarte moderno demokratikoko kide) eta horren gaineko eskubideak dauzkagu, edo bestela, gizarte horretatik baztertuta gaude nolabait, baldin eta parte hartzen ez badugu gizarte osoarentzat antolatutako produkzio-prozesuan”. Nolanahi ere, enpleguaren kalitateak, eta, ikuspegi horretatik, enplegu prekarioaren eta langile pobreen fenomenoaren hedadurak, ezinbesteko eragina dute enpleguaren gaitasun gizarteratzailean. Hala, esaterako, Laparraren iritziz (2006):

Enpleguak (enplegu egonkorra, ongi ordaindua, babes juridikoa eta gizartearen onespena duena) funtsezko betekizuna bete du Europan ia XX. mende osoan garatu den gizarte-integrazioaren ereduan, eta, eraldaketa ugari izan baditu ere, oraindik ere ordezkaezina da alor horretan. Enplegutik aparte, gure gizartek ez dute ahalmen integratzaile nahikoa duen bestelako bide alternatiborik aurkitu [...]. Alabaina, produkzio- eta deslokalizazio-ereduak eraldatzeko prozesuen haritik datozen lan-ezegonkortasuneko prozesuek oso ondorio kaltegarriak ekar ditzakete berekin. Hortaz, enpleguaren kalitatearen gaia gizartekohesioari buruzko eztabaidari, bazterkeriaren dinamikari eta integrazioari buruzko eztabaidari lotzen zaio.

Aldaketa horiek guztiak kontuan hartu behar dira enpleguaren balio integratzaileari buruzko gogoeta egitean. Izan ere, Sartu federazioak adierazi duenez (2010), gaur egungo testuinguruan zenbait kontzeptu zalantzan jarri edota birformulatu beharko lirateke, hala nola enpleguari lehentasuna ematea gizarteratzearen ardatz nagusia den heinean, lana herritartasuna lortzeko ate nagusi gisa, lan-merkatuarekin zerikusia duten zenbait alderdi, prestakuntza eta abar. Hala eta guztiz ere, Sartuk egindako azterlanean parte hartu duten pertsonen iritziz,

gaur egungo krisi-egoeran ere, enpleguak gizarteratzeko bide nagusietako bat izaten jarraitzen du. Gizarteratzea ez da enplegura mugatzen, baina enplegua hartu behar du aintzat ezinbestean, betiere pertsonak laneratzeko adina badu, lanerako ezinduta ez badago eta langabezia-egoera bestelako jarduerak (prestakuntza, hirugarren pertsonen zaintza eta abar) garatzeko aukera hartu izanaren emaitza ez bada. Zailtasunak zailtasun, enplegua gizarteratzearen funtsa da, edozein kasutan.

Ikuspegi horretatik begiratuta, enpleguaren ahalmen gizarteratzailea indartzen jarraitu beharko genuke, nola ikuspegi makroekonomikotik, soldata txikiei eta balio erantsi urriko jarduerei lotu gabeko produkzioeredu baten alde eginez, hala lan-merkatuaren erregulazioarekin zerikusia duen ikuspegitik. Hortaz, gizarteratze aktiboko ereduari buruzko gogoetari dagokionez, enpleguaren kalitatea bilatzen jarraitu behar dugu eta enpleguaren gaitasun gizarteratzailea berreraiki; hori izango da ildo nagusia aurrera begira, dokumentu honetan garatutako printzipioetatik eta LANEk babestutako lan duinaren kontzeptutik abiatuta.

Ezbairik gabe, argi dago enplegu guztiek ez dutela ongizatea, zoriontasuna, gizarteratzea edo bizikalitatea sorrarazteko ahalmen berdina. Eta egia da, halaber, enplegu prekario bat baliagarri izan daitekeela gizarteratze-prozesu batean, gaitasun inklusibo handiagoko egoeretarako trantsizioa errazten duen neurrian. Nolanahi ere, ez dago esaterik prestazio ekonomiko bat jasotzeko neurri soil bat, berez, lanpostu batean integratzea balio inklusiboagoa denik: prestazio ekonomiko hori gizarteratzerantz aurrera egiteko prozesuan txertatzen bada bakarrik esan 
dezakegu prestazioa positiboagoa dela enplegu jakin batzuk baino. Aurrerapen-prozesu horren ezaugarriak aldatuko dira pertsonaren ezaugarri, premia eta trebetasunen arabera -gizarte- eta hezkuntza-arloan esku hartzea, oinarrizko gizarte-trebetasunak berreskuratzea, oinarrizko premiak estaltzea, enplegurako prestatzea, lan babestua eta abar-. Prozesu horrek ez du zertan laneratzearekin lotuta egon, baina lan-merkaturatzea betiere izango da prozesuaren funtsezko helburuetako bat. Kasu horretan bakarrik esan daiteke prozesua inklusiboagoa dela lanpostu prekario bat lortzea baino.

Hortaz, ez laneratze prekarioa ez inolako gizartelaguntzarik gabeko prestazio ekonomikoak ezin daitezke alternatiba egokiak izan, ez batak ez besteak ezin dutelako, berez, gizarteratze-prozesurik sorrarazi. Aitzitik, alternatiba egokia bi aukera horien artean egongo da, eta, horrelakorik behar duten pertsonentzat, gizarteratzeko esku-hartze prozesuak jarri beharko dira abian, premia pertsonalen arabera zenbait tresnatan oinarri daitezkeenak, hala nola laguntza ekonomikoa, enplegurako aktibazioa, gizarte- eta hezkuntza-arloko esku-hartzea eta abar. Azken batean, enpleguaren prekarizazio-prozesuak lan-merkatuaren gaitasun integratzaileari kalte egin diezaioke, eta, arrisku horri aurre egiteko, prestazio ekonomikoei baldintza gutxiago jarri beharrean, gizarteratze aktiboko eredua aplikatu beharko da bere ondorio guztiekin, lan-merkatuaren baldintzen gaineko esku-hartzeari arreta berezia eskainiz.

Aldez aurretik adierazi dugunez, aktibazio-politiken azpiko indibidualizazio-kontzeptuak bere abantailak eta alde onak baditu, baina garrantzizko zenbait arrisku ere nabari zaizkio. Horietako bat langabeziarekin zerikusia duten arazoen despolitizazioa da, eta hortaz, lan-merkatuaren funtzionamenduan eragiten duten egiturazko baldintzei kasurik ez egitea. Alabaina, dokumentu honetan aldarrikatzen den aktibazio-eredu inklusiboak gaiaren birpolitizazioa eskatzen du, eta administrazio publikoei eskatzen die, prestazioen hartzaile direnei baldintzak ezartzeaz gain, bidezko lan-merkatua eta lan duina garatzea ahalbidetuko duten neurriak hartzea ${ }^{4}$.

Víctor Renesek adierazi duenez, enplegua gizartean integratzeko, errenta banatzeko eta gizartea babesteko funtsezko mekanismoa dela proposatzen bada, ez du inolako zentzurik, aldi berean, enpleguaren kondizioei eta kalitateari muzin egitea. Halaber, Whitek planteatutako bidezko elkarrekikotasuneko eskemak zera azpimarratzen du, prestazio horiek jasotzen

${ }_{4}$ LANEk eta lanaren zientzien alorreko adituek 1999an erabili zuten lehen aldiz, esanbidez eta formalki, lan duinaren esapidea, hain zuzen ere Lanaren Nazioarteko Konferentziako zuzendari nagusiaren izen bereko memorian. Lehen definizio bat ere ageri zen: produkziolana askatasuneko, berdintasuneko, segurtasuneko eta duintasuneko baldintzetan, eskubideak babesteaz gain ordainsari egokia eta gizarte-babesa eskaintzen duena. Lehen formulazio horretan, lan duinak honako osagai hauek edukiko lituzke: a) produkzio-lana; b) eskubide-babesarekin; d) diru-sarrera egokiekin, eta e) gizarte-babesarekin. Jarraian dokumentu berean jasotakoarekin bat etorriz, oinarrizko bosgarren ezaugarri bat erantsi beharko genuke: f) hiru alderdi izatea eta gizarte-elkarrizketa. dituztenei baldintza jakin batzuk ezartzen badizkie, Estatuak, trukean, lan egiteko eskubidea bermatu behar du, eta, zentzu orokorragoan, kalitatezko lan duina eta inklusiboa bermatzeko konpromisoa hartu behar du. Hortaz, ezinbestekoa da indibidualizazioaren interpretazioa planteatzea. Ildo horretan, langabeziaren alderdi indibidualei eta bazterkeriari heldu behar zaie, arazo horiek indarrean daudelako eta sarritan oso garrantzitsuak direlako, baina, horretara mugatu beharrean, lan-merkatuan eragiten duten egiturazko alderdiei buruzko esku hartzeari lehentasuna eman behar zaio: ordainsari-mailak, segurtasuna eta higienea lanean, kontratuzko baldintzak, lana eta familia uztartzea, negoziazio kolektiboa, langileek enpresen kudeaketan parte hartzea eta abar. EAEn Gobernuaren Saila da enpleguko eta gizarteratzeko politiken arduraduna, eta ezbairik gabe horrek erraztu egiten du horrelako estrategiak abian jartzea, bidezko elkarrekikotasuneko eta gizarteratze aktiboko eredu batean oinarrizkoak direnak, aldez aurretik adierazi dugunez.

\subsubsection{Enplegagarritasuna hobetzea gizarteratzeko prozesuetan aurrera egiteko tresna egokia den heinean}

Oinarritzat hartu dituen gainerako osagaiekin bat etortzeko, dokumentu honetan aldarrikatutako gizarteratze aktiboko ereduak, ezinbestean, enplegagarritasunaren ikusmolde zabala hartu behar du aintzat, besteak beste McQuaid eta Lindsay egileek adierazi dutenarekin bat etorriz (2005).

Oro har, enplegagarritasuna indibidualtasunari lotuta definitu ohi da. Caritasek (1999), esaterako, honela definitu du enplegagarritasuna: "pertsona baten enplegu-eskaintza batera egokitzeko gaitasuna, batetik, gaitasun horretan eragiten duten faktoreen kudeaketa egokiaren ondorio dena, eta, bestetik, lan-merkaturako bidea errazten dioten jarrera, interes, motibazio, jakintza, prestakuntza edo gaitasunen baturatik eratortzen dena". Caritasek darabilen kontzeptua oinarrizko hiru alderditan eragiten du, hain zuzen ere gaitasunean, egokitzean eta ikaskuntzan, prozesu-ideiari lotuta, eta bereziki alderdi pertsonalei ematen die lehentasuna, hala nola jarrerak, gaitasun pertsonal eta profesionalak, gizarte-eragileak eta abar. Enplegagarritasunen ideiari, ordea, zenbait kritika egin zaizkio, funtsean osagai indibidualei lehentasuna ematen dielako testuinguru-elementuen aurretik, eta aktibazioari buruzko literaturan sarri aurkitzen ditugu kontzeptu horri buruzko kritikak. Serrano Pascualen ustetan (2001), Enpleguko Europako Estrategiaren eta aktibazio-estrategia nazionalen esparruan zehaztu denez, enplegagarritasunak langabeziaren ikusmolde jakin bat dakar gogora eta, horren arabera, langabeak dira errudunak merkatuaren premietara ez direlako egokitzen, lan-merkatuaren barneko aukera-urritasuna aintzat hartu beharrean.

McQuaiden eta Lindsayen aburuz (2005), enplegagarritasun-kontzeptua modu askotara uler daiteke: 
ikuspegi horien guztien artean ${ }^{5}$, egile horiek enplegagarritasunaren ikusmolde elkarreragilea sustatu nahi dute Horri jarraiki, enplegagarritasunak hainbat oztopo indibidual eta sozial gainditzearekin du zerikusia, pertsonei enplegurako sarbidea galarazten dietenak; gainera, enplegagarritasuna sustatzeko politikek ez lituzkete gizabanakoak soilik aintzat hartu behar. Alabaina, aktibazio-politika gehienek oinarritzat hartu duten ikusmoldearen arabera, enplegagarritasunak, funtsean, gabezia indibidualekin du zerikusia, testuingurua eta egitura alde batera utzita. Kritika horietatik abiatuta, McQuaidek eta Lindsayek enplegagarritasun zabaleko kontzeptua planteatu dute, eta, horren arabera, ezaugarri eta zirkunstantzia indibidualek baldintzatzen dute enplegagarritasuna handiagoa edo txikiagoa izatea, baina baita kanpoko beste hainbat eragile sozial, instituzional eta ekonomikok ere, pertsonen enplegu bat lortzeko gaitasunean eragiten dutenak.

Hortaz, enplegagarritasun zabaleko kontzeptuak eragile indibidualen eta kanpoko eragileen arteko elkarreragina hartzen du hizpide, eta horik enplegagarritasun elkarreragilearen kontzeptua. Ikuspegi horretatik, gaitasun indibidualen, zirkunstantzia pertsonalen, lan-merkatuaren baldintzen eta testuinguruaren beste zenbait eragileren artean elkarreragin bizi bat indarrean dagoela azpimarratzen du.

McQuaidek eta Lindsayek enplegagarritasunaren ikusmolde zabala planteatu dute, beraz, eta, horren arabera, testuinguruaren baldintzatzaileak alde batera utzita gizabanakoa soilik aintzat hartzen duten ikuspegi guztiak zalantzan jartzen dira, baita, gizarteratze-prozesu ororen azpian dauden lanmerkatuaren zirkunstantzia aldakorretara egokitzeko eta ahalegintzeko ekimen pertsonalarekin zerikusia duen osagaia aintzat hartu gabe, egiturazko neurriez bakarrik arduratzen direnak ere. Beraien lanetan bildutako adibideek agerian uzten dute, halaber, enplegagarritasuna hobetzeko politikak eta programak zenbateraino heda daitezkeen, ikusmolde elkarreragin eta erlatibo batetik abiatuta. Izan ere, enplegagarritasunaren ikusmolde absolutu batetik urrun, kontzeptuari dimentsioa erlatiboa eman behar zaio. Izan ere, testuinguruaren arabera, gaitasun pertsonal berberek -jakintza berberek, trebetasun berberek, prestasun berberek- oso balio desberdina izan dezakete baldintzen arabera, ziklo ekonomikoaren arabera esaterako.

${ }^{5}$ Egile horiek honako bereizketa hau egiten dute: a) enplegagarritasunaren kontzeptu dikotomikoa (pertsona enplegagarriak eta pertsona enplegaezinak); b) gizarte- eta osasun-interpretazioa, urritasunak edo desgaitasunak dituzten pertsonak laneratzeko gaitasunari lotuta; d) giza baliabideen kudeaketarekin zerikusia duen interpretazioa, enplegagarritasuna lan-merkatuaren eskakizunetara egokitzeko gaitasun handiagoarekin edo txikiagoarekin lotzen duena; e) enplegagarritasuna enplegu-politiken emaitza objektiboa dela ezartzen duena; f) langileen malgutasuna, prestakuntza eta ekimen indibiduala indartzearekin zerikusia duena; eta g) enplegagarritasun elkarreragilea, ekimen indibiduala azpimarratzen badu ere, enplegagarritasunean testuinguruak, enplegu-eskaintzak eta lan-merkatuaren erregulazioak ere eragiten dutela onartzen duena.
Gaur egun gizarteratzearen arloko gaietan diharduten erakunde aurrerakoiek zera azpimarratzen dute, aktibazio-politikek ez dituztela enplegu-eskaintzarekin zerikusia duten gaiak bakarrik landu behar, eta, gai horiei ez ezik, enpresen lanpostuen eskariaren arloko gaiak ere aintzat hartu beharko lituzketela. Hala, Britainia Handiko Institute for Public Policy Research (IPPR) erakundea aktibazio-politikak egokitzeari buruz egiten ari den gogoeta zabalaren esparruan, Landingek (2010) zera azpimarratu du, laneskarian esku hartu beharra dagoela, areago oraindik langabezia-tasak handiak direnean, eskaintzaren ezaugarrietan soilik esku hartu beharrean, langabeen enplegua lortzeko aukerak hobetu ahal izateko. Landingen aburuz, "ongi ordaindutako enplegu iraunkorren gorakada sustatzeko neurriak funtsezkoak dira lan-merkatu justuagoak eta orekatuagoak sortzeko, ekonomia suspertu ahala”. Ikuspegi horrek oso sustraitua dagoen ideia bat zalantzan jartzen du, pobreziaren tranparen teoria oinarritzeko ere neurri handi batean erabili dena. Horren arabera, langabeziaren arrazoi nagusia ez da lanposturik ez izatea, langileek lanpostu horiek betetzeari uko egitea edota langabeen trebetasunik edo prestasunik eza baizik. Ildo horretan, aipatu berri dugun enplegagarritasun zabaleko kontzeptuarekin bat dator.

\subsection{Diru-sarrerak bermatzeko baldintzazko eredua, bidezko elkarrekikotasunaren kontzeptuan oinarritua}

\subsubsection{Prestazioen baldintzazkotasunaren justifikazioa eta bidezko elkarrekikotasunaren kontzeptua}

Aldez aurretik adierazi dugunez, gizarteratze aktiboko eredua justifika daiteke, batetik, herritarrek gizarteratzeko eta laneratzeko laguntza jasotzeko eskubidea dutelako, eta, bestetik, baldintzazkotasun- eta elkarrekikotasun-printzipio batzuk aplikatzea beharrezkoa delako. Izan ere, diru-sarrerak bermatzeko prestazioak jasotzean, baldintzazkotasuna funtsezko osagaietako bat da prestazio horien aktibazioari buruzko eztabaida akademikoan, eta, aldez aurretik ikusi dugun bezala, prestazio horiei egin zaizkien kritika gehienen oinarria ere bada. Aktibazioa ez da soilik baldintzazkotasunaren edo elkarrekikotasunaren arabera babestu edo aplikatu behar, hau da, ez da betekizun, erantzukizun edo betebeharretara mugatu behar, baina aldi berean argi dago, Marshallek aldarrikatu zuenez, herritartasunaren eskubideak eta betebeharrak uztartzen dituen diskurtso bati jarraiki ulertu behar dela.

Diru-sarrerak bermatzeko sistemen baldintzazkotasuna honako ideia honetan oinarritzen da: prestazio horien hornidura herritarraren eta komunitatearen arteko kontratuaren alderdietako bat da. Estatuak herritarrari legez agin diezazkiokeen betebeharrek osatzen dute beste alderdia. Aktibazioaren kritiko gehienek ez bezala, Whiteek (2000) ez du onartzen kontratuan oinarritutako gizarte-eskubideen ikuspegi hori atzerapena izatea Ongizate Estatuaren garapenean, eta, aitzitik, kontratua bidezko sistema ekonomiko bat garatzeko beharrezko betekizuna dela uste 
du, gizarte-produktuaren zati baten onura jaso nahi dutenek, beren herrikideen produkzio-ahaleginaren kontura bizi beharrean (hori esplotazio modu bat izango litzateke, Whiteren iritziz), beren ekarpena egiten dutela bermatzen duen neurrian.

Whiteren iritziz, baldintzazkotasun-printzipioa lanbetebeharrei aplikatzea legezkoa da, eta legitimitate hori elkarrekikotasunaren ideian oinarritutako justizia banatzailearen noziotik abiatzen da: gizarteproduktuaren onura jasotzen duen orok, trukean, komunitateari arrazoizko ekarpen produktibo eta proportzionala egin behar dio. Prestazio ekonomiko bat jaso behar dutenei enplegu batean jarduteko edo jarduteko prest egoteko baldintza jartzea bidezkoa da, beraz. Izan ere, elkarrekikotasun-printzipioak eskatzen duen ekarpena egin gabe gizarte-produktuaren onura jaso nahi dutenen asmoa saihestu daiteke horrela. Egile horren logikan, elkarrekikotasun-printzipioa garrantzitsua da, berez eta ikuspegi instrumental batetik:

a. Funtsezkoa da gizarte-produktuaren zati baten onura jasotzen duten herritarrek arrazoizko ahalegin bat egitea beste batzuek ere gizarte-kidetasun horretatik onura jaso dezaten, eta, beraz, herritar batzuek besteei gehiegizko karga ezar ez diezaieten, sen onari jarraiki hori saihesteko moduan egonik. Hortaz, gutxieneko diru-sarrerak baldintzarik gabe jasotzeko aukera ematea ez litzateke bat etorriko guztion ongirako elkarrekiko lankidetzarako oinarrizko arauekin, eta, ikuspegi horretatik, esplotazio modu baten aurrean egongo ginateke. Desberdintasunezko jarrera batetik urrun, Whiteren ustetan elkarrekikotasun-printzipioa elkartasunaren etikaren adierazpidea da. Haren hitzetan: "elkarrekikotasun-printzipioaren arabera, batetik, herrikideei laguntzen diet, beren ardura ez den gertaera baten ondorioak pairatzen dituztenean, eta, bestetik, arrazoizko ahalegin bat egiten dut nire herrikideei ondasunak eta zerbitzuak eskaintzeko, haiek eskaintzen dizkidaten ondasunen eta zerbitzuen truke". Whiteren iritziz, elkarrekikotasun-printzipioa oso sustraitua dago giza portaeran, psikologiaren, ekonomiaren edo biologia ebolutiboaren alorretako ikerketa ugarik agerian utzi dutenez, eta ez da, inondik inora, inolako ondoriorik gabe bazter daitekeen tramankulu ideologiko soila. Berdinzaletasun ekonomikoan oinarritutako edozein proiektuk porrot egin dezake baldin eta elkarrekikotasunaren araua kontuan hartzen ez badu, eta zentzu horretan egiten den erreforma oro printzipio horretan oinarritu beharko litzateke argi eta garbi, alde batera utzi beharrean

b. Ikuspegi instrumentalago batetik, Whiteren iritziz elkarrekikotasun-printzipioa kontuan hartzekoa da, horren ez-betetze nabariak baliorik gabe uzten duelako Ongizatearen Estatuaren oinarrian dauden erabakien legitimitatea, eta bereziki baldin eta erabaki horiek hainbat herritarren ahalegin handia eskatzen badute. Gizarte-berdintasuneko helburuak lortzeko, aprobetxamendu- eta parasitismo-arriskuak hartu behar dira kontuan. Bestela, helburu horiek sustatzen dituzten erakundeak eta helburu horien oinarrian dagoen espiritu solidarioa zalantzan jar genitzake.

Whiteren tesiari jarraiki, elkarrekikotasun mota hori, nolanahi ere, ez da kontuan hartu beharreko gauza bakarra justizia birbanatzaileari dagokionez. Aitzitik, kolektibitateak prestazio ekonomikoen onuradunei legez zer eskatu behar dien neurtzeko, gizarte horrek gizarte-justiziaren gainerako dimentsioak zenbateraino betetzen dituen hartu beharko da kontuan. Hortaz, bidezko elkarrekikotasun-printzipioaren arabera, aktibazioaren azpiko kontratu-mekanismoaren legitimitatea neurtzeko, kolektibitateak berdintasuneko, birbanaketako eta gizarte-justiziako oinarrizko irizpideak zenbateraino errespetatzen dituen hartu beharko dugu aintzat.

Hortaz, Whiteren aburuz, guztion ongiari ekarpenen bat egiteko betebeharra, elkarrekikotasun-printzipioaren azpian dagoena, dagokion testuinguru sozioekonomikoaren barnean bakarrik ezar daiteke. Hau da, ekarpen hori esparru jakin batean egin behar da, ondasunak eta aukerak banatzeko esparru jakin batean alegia. Bestela, zera sustatuko genuke, haren iritziz, argi eta garbi desorekatua den gizarte batean desabantailazko egoeran dauden pertsonek beren esplotazioari eusteko ekarpenak egin behar dituztela. Egile horren ustetan, elkarrekikotasun-printzipioa aplikatzean tokiko baldintzatzaile sozioekonomikoak alde batera uzten badira, Estatu Batuetan gertatu den bezala, gizarte-politika guztiz zigortzaile bihur daiteke, eta horregatik funtsezkoa da azpimarratzea elkarrekikotasun-printzipioak inplikazio bikoitza duela: batetik, komunitateak ahalegin berezi bat egin behar du birbanaketaren arloan oinarrizko maila bat bermatzeko, eta, bestetik, herritarrari itunetik dagokion zatia betetzeko eskatu behar zaie.

Testuinguru sozioekonomiko jakin batek bidezko elkarrekikotasuna aplikatzeko errespetatu beharreko betekizunetako batzuk zerrendatu ditu Whitek:

- Gizarte-produktuan gutxieneko parte-hartzea edukitzeko bermea, produkzioan parte hartzeko gutxieneko estandarrak errespetatzen dituzten guztientzat (edo, bestela, esanda, zenbateko nahikoak diru-sarrerak bermatzeko prestazioen zenbatekoak zehaztean, eta soldata-konpentsazioko mekanismoak jasotzeko eskubidea, baldin eta produkzio-sistemak eskainitako ordainsariak nahikoak ez badira oinarrizko premiak estaltzeko edota, epe laburrean, gizarte jakin batean itxarondako gutxieneko erosotasun- eta ongizate-mailei eusteko beharrezkotzat jotzen diren ohiko gastuei aurre egiteko).

- Produkzioan parte hartzeko behar adina aukerak (edo, bestela, esanda kalitatezko lan duina edukitzeko eskubidea eta egin beharreko lanjarduerei dagokienez aukera sorta bat edukitzeko eskubidea, ezin dezakegulako legezkotzat jo pertsonak oso jarduera gogor edo desatseginetan jardutera behartzea, baldin eta horrek gutxieneko bizi-gogobetetasuna galarazten badie). 
- Produkzioan parte hartzeko modu guztiak antzekotzat jotzea, etxeko edo familiako zaintzako lanak, boluntario-lanak, komunitate-garapena eta arte-zeregina ere komunitateari ekarpenak egiteko modu legitimoak direla onartuz, zeregin horiek guztiak ordaindutako enpleguaren parean jarriz.

- Elkarrekikotasun-printzipioaren aplikazio unibertsala eta proportzionala, edo, bestela esanda, betebehar jakin batzuk ezartzea, zergaarlokoak esaterako, herentzia bidez, prestazio ekonomikoen hartzaile direnei eskatzen zaizkien produkzio-ekarpenak egin gabe, ondasunen onuradun direnentzat. Gainera, zenbait neurri jar daitezke ekarpenaren tamaina mailakatzeko, pertsona bakoitzak eskura dituen ondasunen arabera (zerga-gehikortasuna ${ }^{6}$ ).

Zenbateraino errespetatu behar dira printzipio horiek gizarte-prestazioen baldintzazkotasuna legez erreklamatu ahal izateko? Oso-osorik betetzen ez badira, horrelako prestazioen hartzaileak beren konpromisoak betetzetik salbuesteko aukera dago? Whiterentzat, aukera hori gehiegizkoa da. Haren iritziz, aukera-berdintasunaren eta aberastasuna birbanatzearen alorretan maila egoki bat, baina ez goreneko maila, lortu duten herrialdeetan, Suedian adibidez, bazterkeria-egoeran dauden herritarrek ezarritako testuinguru sozioekonomikotik behar adina etekinik ateratzen dute, eta horregatik legezkoa da haiei ekarpen jakin bat eskatzea, bidezko elkarrekikotasunaren printzipioa betez.

Irizpide horiek bete-betean bete daitezela eskatu beharrean, Whitek, beraz, gutxieneko atalase-mailen irizpide baten alde egin nahi du: elkarrekikotasun unibertsaleko printzipio batean oinarrituta, komunitateari produkzio-ekarpen bat egin behar zaio, baldin eta dagokion komunitateak aukera-berdintasunen gutxieneko atalase-maila lortu badu. Herritar guztiek beren ekarpena egin behar dute, baldin eta lankidetzaren etekinen banaketa gutxienez bidezkotzat jo daitekeen tartearen barruan baldin badago.

Ildo horretan, bidezko elkarrekikotasunaren kontzeptua ezin daiteke Ongizate Estatuaren babesean bildutako zerbitzu eta prestazioen multzotik bereizi. Izan ere, esparru jakin batean biztanle guztien eskura gizarte-, hezkuntza- eta osasun-zerbitzuen sare zabala badago, eta zerbitzu horiek muga batzuk izanagatik ere, doakoak, arrazoizko kalitatezkoak eta estaldura zabalekoak badira, orduan bidezko elkarrekikotasunaren betekizuna behar bezala estaltzen ari dela esan dezakegu. Ezbairik gabe, printzipio hori aplikatzeko ezinbestekoa da erakunde publikoek ere lan-merkatuaren kalitatean eta lan-baldintzetan irmotasunez esku hartzea, baina nekez esan daiteke diru-sarrerak bermatzeko prestazioak jasotzen

\footnotetext{
${ }^{6}$ Izan ere, Whiteren iritziz, gizarte-politikako baldintzazko edo zein eredu legitimok zergak ezarri behar dizkie nola ondorengotzei hala ondareari, bide horretatik elkarrekikotasun-printzipioa urra ez dadin saihesteko.
}

produkzio-ahaleginaren edo laneko parte-hartzearen arloetako konpromisoak betetzetik lan-merkatuaren ezegonkortasuna dela medio, baldin eta, oro har, guztion ahaleginetik etekina ateratzen ari badira, gizarte-, osasun- edo hezkuntza-zerbitzuak doan eskuratuz. Ildo beretik, kontuan hartzekoa da merkatua askea izaki, ekintza publikoak lan-merkatuaren ezaugarri jakin batzuetan eragiteko duen gaitasuna urria dela, eta horrek, jakina, bidezko elkarrekikotasunaren kontzeptua baldintzatzen duela.

Whiteren ustetan, gizarte batek betekizun horiek betetzen baditu, gizarte-produktuan eskuzabaltasunez parte hartu nahi duen edozein pertsonak komunitateari produkzio-ekarpen bat egin behar dio nahitaez, oinarrizko lan-itxaropena ekar dezakeena, jarduera zibikoetan gutxieneko ordu kopuru bat sartuz. Zerbitzu batek komunitatearen mesedetan sortutako jarduera mota guztiak bilduko lirateke kontzeptu horren barnean, hala nola ordaindutako lana, guraso-zaintzak, mendekoentzako arreta edo etxeko lanak. Whiteren proposamena urrun dago gutxieneko diru-sarrerak jasotzeko eskubidearen baldintzazkotasuna ulertzeko, kontratuari garrantzi txikiagoa ematen dioten beste ikusmolde batzuetatik. Meadek edo Selbournek, adibidez, araua nahitaezkoa dela azpimarratzen dute, eta komunitateak prestazio ekonomikoaren ekarpena egitea, berez, nahikoa dela uste dute.

\subsection{Garapen pertsonalerako eta gizarteratzeko eskubidea, aktibazio-politiken esparruan}

\subsubsection{Bazterkeriaren kausa anitzeko izaera eta gizarteratzearen dimentsio anitzeko errealitatea onartzea}

Aldez aurretik adierazi dugunez, proposatutako eskemaren oinarrizko kontzeptuzko hirugarren alderdiak ezarritako aktibazio-neurrien izaera inklusiboarekin du zerikusia.

Ezbairik gabe, gure ingurunean gizarteratzea integrazioaren sinonimo edo baliokide gisa erabili da bereziki. Nolanahi ere, kontzeptualizazio gutxi batzuen arabera, bata eta bestea ongi bereizi dituzte, argudio sendoak emanez. Hala, gizarteraztearen kontzeptua integrazioaren sinonimo gisa erabili da, baita normalizazioaren sinonimo gisa ere, eta kontzeptu horiek zenbait kritika jaso dituzte ezgaitasunaren eremuan adibidez, ezgaitasunaren osasunedo errehabilitazio-ereduarekin identifikatu direlako. Horregatik, batzuetan gizarteratzea normalizazio/ integrazio-ereduaren aurrerapena dela esaten $\mathrm{da}^{7}$.

\footnotetext{
${ }_{7}$ Agian hezkuntzaren eremuan nabarmendu dira gehien integrazioaren eta gizarteratzearen arteko alde horiek. Hala, pedagogiaren eremuan, eskolak aniztasunari erantzuteko erabili beharreko jarraibideekin du zerikusia gizarteratze-kontzeptuak. 9oeko hamarkadan sortutako hitz horrek integrazioa ordeztu nahi zuen, hezkuntzajardunbidean ordura arte nagusi izan zena. Oinarrizko xedea da eskola-sistema aldatu beharra dagoela ikasle guztien premiei erantzuteko, ikasleak sistemarekin bat eginez sistemara egokitu beharrean. Eskolan kontzienteki eta nahita heterogeneotasunaren alde egitea da ikuspegi inklusiboaren funtsezko zutabeetako bat.
} 
Ildo beretik, Renzagliak eta beste batzuek (2003) adierazi dutenez, integrazioa -norbait sistema bateratu batean txertatzea alegia- eta gizarteratzea bereizi behar dira, azken kontzeptu horrek desberdintasunari balio positiboa ematea eta pertsona guztien premiei erantzutea eskatzen duen heinean. Ikuspegi horretatik, eta modu sinplista samarrean bada ere, integrazio-ideiaren aldean, gizarteratzekontzeptua nolabait ezgaitasunaren gizarte-ereduarekin uztar liteke, gizarte-inguruneen baztertzeko joera handiagoari edo txikiagoari lehentasuna ematen dion heinean.

Hortaz, gizarteratze-kontzeptua, nolabait, aurrerapauso bat da berez bazterkeria-sortzailetzat jo daitezkeen beste kontzeptu batzuen aldean, normalizazioaren aldean adibidez. Izan ere, pertsona ezgaituek (edo, lan honen xedeetarako, langabeak edo desabantailazko edo bazterkeriako beste edozein egoera pairatzen dutenak) pairatzen duten bazterkeriaren arrazoia pertsona horien errealitatearekin bat ez datorren arau baten ezarpenean egon liteke. Izan ere, ezgaituak "ezinduta egon litezke gizarte-bizitzaren oinarrian dauden hainbat jardueratan parte hartzeko, eta, gauzak horrela, eguneroko bizitzaren ohiko korrontetik aparte geratuko lirateke. Hori hala da eguneroko bizitzako egituretarako -hezkuntza, lana, familia, gizarte-elkarreragina eta abar-sarbide guztiak, neurri handi batean, nagusi den arauari jarraiki -ez-ezgaituei dagokiena, kasu honetanezartzen direlako. Hala, normalean hautatutako arauari buruzko desberdintasun edo desbideratzeetarako egokitzapenik aurreikusten ez denez, desberdintasuna diskriminazio fin (eta batzuetan ez hain fin) baterako oinarri gisa erabiltzen da" (Palacios eta Bariffi, 2007).

Ildo horretan, eta Mike Oliver gogora ekarriz, ezgaitasunaren gizarte-ereduaren aitetako bat den heinean, egile horiek gizarteratze-kontzeptua planteatu dute haien ustez gainbehera datorren integrazio-eredu bat gainditzeko edo eredu horretan aurrera egiteko: "integrazio-ikuspegi zaharraren arabera, desberdinak direnek gainerako guztien onarpena eta tolerantzia izan behar dute. Alabaina, integrazio-ikuspegi berria -edo, egileen ustetan, gizarteratzea- guztiz bestelako filosofia batean oinarritzen da, nortasun pertsonalaren politikan alegia. Ikuspegi horri jarraiki, desberdintasuna toleratzea eta onartzea ez da nahikoa, eta modu positiboan baloratu behar da”. Hortaz, honako parekatze hauek egin genitzake, metaforak erabiliz: integrazioa pieza bat aldez aurretik zehaztutako molde batean txertatzea litzateke; gizarteratzeak, berriz, molde malguak sortzearekin izango luke zerikusia, eta molde horiek malgumalguak beharko lukete, askotariko piezen ezaugarrietara egokitzeko modukoak.

Hortaz, ikuspegi horren arabera, gizarteratzea batetik, eta integrazioa edo normalizazioa bestetik, bereizi beharko lirateke, dokumentu honetan aipatu diren konpromiso bikoitzeko eta enplegagarritasun zabaleko kontzeptuekin bat etorriz. Horiek guztiek era batera edo bestera adierazi dute gizarteratzea- ren zama guztia ez dela langabezia-egoeran dagoen pertsonaren gainean utzi behar, eta, hortaz, testuingurua edo egituretan ere eragin beharko litzatekeela uste dute, pertsonen premia eta aukeretara egokituz.

Bestetik, gizarteratzearen paradigma aplikatzeko, behar-beharrezkoa da bazterkeriaren kausa-aniztasuna eta horren inplikazioak onartzea. Izan ere, adostasun-maila handia lortu da gizarte-bazterkeria pertsonaren bizitzako oso eremu desberdinetako -hezkuntza, etxebizitza, osasuna, enplegua, eskubide politikoak, harreman pertsonalak eta abardesabantaila-metaketa dela zehaztean. Bazterkeriaren kasua anitzeko ikusmoldea ez dator bat aktibazio modu jaki batzuekin, gizarteratzea eta laneratzea parekatzean dutenez, gizarteratze-prozesuen kausa anitzeko osagaia kontuan hartzen ez dutenak. Ildo horretan, eta aldez aurretik esan dugun bezala, argi badago ere enplegua lortzea gizarteratzeko funtsezkoa dela, ezin dezakegu ahaztu enplegua ez dela, berez edo bakarka, gizarteratzea bermatzeko nahikoa. Izan ere, kasu edo egoera jakin batzuetan litekeena da gizarteratze-prozesuek laneratzearen premiarik ez izatea, eta bizitzaren beste dimentsio batzuei lehentasuna eman behar izatea.

Izan ere, Pérez Eransusek dioenez (2006), “gizarteratzea autonomia eta mendetasuna hobetzeko gaitasunez jabetzeko prozesutzat jotzen badugu, prozesu hori ez da lan- edo prestakuntza-jarduera bat egitera mugatu behar. Gizarteratzea gizarte-laguntzako prozesu iraunkorra da, berekin baliabideen sinergia ekarri beharko lukeena, jarduerak egiteaz gain, trebetasunez jabetzea, gizarte-problematikak konpontzea, babes-sistemak eskuratzea eta abar barne hartuta8". Izan ere, egile horrek beste artikulu batean adierazi duenez (Pérez Eransus, 2009), azken urteetan aktibazioaren "ikusmolde zabalago bat" nagusitzen ari da, eta, "horren arabera, aktibazioak lanaren eremua gainditu nahi du, eta beste zenbait eremu bildu, hala nola gizarte parte-hartzea, gizarte-harremanak edo aisia". Bestetik, ideia hori guztiz bat dator aktibaziorako esku-hartzeen indibidualizazioaren ideiarekin, pertsona bakoitzaren premia eta aukerak kontuan hartu behar direlako gizarteratze-prozesuaren fase bakoitzean.

Euskadin laneratzearen eremuan diharduten erakundeek antzeko iritziak dituzte. Hala, Sarturen ustetan (2010),

gizarteratzean faktore anitz biltzen direla esaten badugu, ezin dezakegu kausa edo faktore bakar baten arabera azaldu, gizarteratze-prozesuei heltzerakoan ezin dezakegu faktore horietako bakar bat aintzat hartu, enplegua, etxebizitza edo osasuna izan, eta faktore guztiei erantzuten dieten prozesu integralak antolatu behar dira.

${ }^{8}$ Egilearen ustetan, gizarteratzea produkzio-jarduerak garatzera mugatze hori gutxienekoen prestazioak jendaurrean legitimatzeko helburuarekin sortu zen, eta, horrela, baliabidearen kronifikazioaren eta eraginkortasun-galeraren eraginaren haritik sortutako beldurrak uxatzeko. 
Nolanahi ere, egungo krisi-une honetan ere enplegua gizarteratzeko bide nagusietako bat izan arren, enpleguarena ez da bide bakarra.

\subsubsection{Gizarteak baloratutako jardueretara irekitako eredua, baina ordaindutako enplegua lortzeari lehentasuna ematen diona}

Aktibazioaren ereduari egin zaizkion kritikak azaltzeko aipatu ditugun proposamenek giza jokabidearen eta lanaren ikuspegi eudemonikoa ezartzeko joera erakutsi dute, lanerako bizi beharrean bizitzeko lan egin behar dela adieraziz. Izan ere, lanak askoren errealizazio pertsonalerako eta bizi-gogobetetzerako zeregin garrantzitsua betetzen duela alde batera utzi beharrean, egia da lanaren balioa ikuspegi pragmatikoagoetatik interpretatu beharko litzatekeela, gizarteak baloratutako jardueren multzora zabalduz, hainbatetan aipatu den bezala. Ildo horretan, egile askoren aburuz aktibazio-kontzeptua ez litzateke ordaindutako enpleguaren eremura mugatu behar, eta gizarteari beste zenbait ekarpen egin beharko lizkioke, bereziki, baina ez bakarrik, familia-zaintzen eta komunitate-ekintzaren eremuan. Ildo horretan, aldez aurretik aipatu dugun bidezko elkarrekikotasunaren printzipioaren arabera, ekarpen mota guztiak hartu behar dira aintzat, batzuk arbitrarioki lehenetsi edo baztertu beharrean, eta, ildo horretan, produkzio-ekarpenaren kontzeptua ez litzateke ordaindutako enplegura mugatu behar (White, 1999).

Moreira (2008) da produkzio-ekarpenaren kontzeptua beste jarduera batzuetara zabaldu beharra gehien azpimarratzen duen eta sendoen justifikatzen duen egileetako bat. Whiteren lan zibikoaren kontzeptuan oinarrituz, Moreirak zera adierazi zuen, bidezko elkarrekikotasunaren betekizunak beteko lituzkeen ekarpen baliodun batek lan arruntaren merkatuan parte-hartzeari lehentasuna eman beharko liokeela, ondasunak eta zerbitzuak elkartrukatzeko lehentasunezko osagaia den heinean, baina aldi berean ondasun publikoen edo baliagarritzat jotzen diren ondasunen -hala nola etxeko lana, haurren arreta edo beste jarduera batzuk, betiere gizartearen benetako premiei erantzuten badieteprodukzioari ere garrantzia eman beharko lioke. Moreiraren aburuz, ikuspegi horren arabera, honako hauekin zerikusia dutenak jo beharko lirateke baliagarritzat produkzio-ekarpen gisa:

a. Ordaindutako enplegua sektore pribatuan.

b. Ordaindutako enplegua sektore publikoan.

d. Borondatezko edo ordaindutako lana gizarteekonomiako erakundeetan, baldin eta, sektore publiko edo pribatuak betetzen ez dituzten gizarte-premiei erantzuteko, ondasun eta zerbitzuen produkzioan parte hartzen badute.

e. Guraso-arreta, gizarte-ugalketarako oinarrizko baldintzak bermatzen dituen neurrian. f. Mendekoentzako arreta, pertsona horiek beren kabuz bete ezin ditzaketen zenbait premia betetzen dituen heinean.

Argudio horren harira zera erantsi behar da, aldez aurretik esan dugun bezala, pertsona bakoitza gizarteratze-prozesuko zein fasetan dagoen hartu behar dugula aintzat. Hala, pertsona batzuentzat ekarpenik logikoena lanpostu bat lortzea izango litzateke; beste batzuentzat, aldiz, eraginkorragoa eta bidezkoagoa litzateke prestakuntza-programetan, errehabilitazio psikosozialeko programetan edo oinarrizko lan- eta harreman-gaitasun batzuez jabetzeko programetan parte hartzeko aukera ematea.

De la Calek eta De la Fuentek (2010) antzeko argudioak planteatu dituzte. Egile horien ustetan, lanaren kontzeptua zabaldu behar da, “ordaindutakoa eta ordaindu gabea barne hartuta. Gure gizarteetan baliagarri eta beharrezkoak diren zeregin guztiak zehaztu beharko lirateke. Ildo horretan, etxeko lanari, zaintza-lanari eta borondatezko lanari adibidez, gaur egun ukatzen zaizkien balorazioa eta onespena onartu beharko litzaieke. Prestakuntzaeta hezkuntza-jarduerak ere lanaren parean jarri beharko lirateke, etorkizuneko garapen ekonomiko eta sozialari egiten dioten ekarpena aintzat hartuta. Garrantzizko urratsa izango litzateke hori. Izan ere, lan horien guztien arduradunek enpleguaz bestelako rol alternatiboak beteko lituzkete gizartean, baina gizarteak berdin-berdin onetsi, legitimatu eta balioetsiko lituzke. Jarduera horien bitartez, pertsonek gizartea hobetzen eta mantentzen laguntzen dute, eta horregatik jarduera horien ahalmen inklusiboa handia da, betiere gizarteak ekarpen hori onesten badu. Enpleguaz aparteko lanaren definizioa ez da zeregin tekniko soila, gizartearen balio eta objektiboetan ongi sustraitutako proiektu politikoa baizik".

\subsection{Gizarteratzeko prozesuen ikusmolde indibidualizatua, egiturazko faktoreak ere aintzat hartzen dituena}

\subsubsection{Pertsonarengan oinarritutako aktibazioa}

Aktibazioaren ohiko paradigmaren alde zein kontra duden guztiak bat datoz indibidualizazio-kontzeptuaren garrantzia azpimarratzean. Izan ere, testuinguruko eta egiturazko faktoreek langabezia- eta bazterkeria-egoerak sortzean duten garrantzia azpimarratu behar da, baina, aldi berean, faktore indibidualek ere egoera horiek gainditzeko garrantzi handia dutela onartu behar da. Hala, esaterako, Sarturen Gizarte Bazterketa eta Gizarteratze Prozesuen Behatokiak (2005), gizarteratzeko ibilbide arrakastatsuen azpian dauden faktoreak azaltzean, zera adierazi zuen, ibilbide horiek arrakasta izan dezaten, pertsonak bere egoera aldatzeko premia sentitu behar du, eta, esanbidez edo isilbidez, hobekuntza-plan bat ezarri behar du. Gaitasun pertsonal jakin batzuk -autoestimazioa, segurtasuna eta abar- eta gizarte eta familia-harremanen sare sendo bat edukitzea eta prestakuntza (berekin dakartzan harreman-alderdiei 
dagokienez bereziki) funtsezkoak dira hobekuntzaprozesu horiek azaltzerakoan.

Hortaz, aktibazio-eredu legitimo batek ez dio zerbitzu indibidualizatuak emateko helburuari uko egin behar, baldin eta zerbitzu horiek pertsonen premietara egokitzen badira, pertsona horiek zer egoeratan dauden eta nola bilakatuko diren aintzat hartuta, eta baldin eta oso askotariko premia, espektatiba eta aukerei erantzuteko behar adinako malgutasuna badute. 1999an Caritasek enplegu-politikak pertsonalizatzeko eredu bat planteatu zuen, batetik, langabezia arazo makroekonomiko erantsi gisa har ez zedin saihesteko, eta, bestetik, neurrien despertsonalizazioa galarazteko, oso askotariko problematikei era berean heltzen dieten bereizkuntzarik gabeko neurri unibertsalak aplikatuz. Ildo horretan, Caritasek enplegagarritasun-eredu bat garatu nahi zuen honako hauetan oinarrituta: jarrera-aldaketa, gaitasun pertsonalen garapena eta enplegu-bilaketa aktiboaren sustapena, enplegagarritasuna garatzeko plan indibidualizatuen bitartez.

Erresuma Batuan eta beste zenbait herrialdetan egin berri diren zenbait proposamenek helburu hori ezarri dute ${ }^{9}$, pertsonarengan oinarritutako aktibazio-eredu bat garatu nahi dutelako (Harker eta Oppenheim, 2007), egungo lagun-egite ereduen zorroztasunaren eta gehiegizko uniformetasunaren aldean ${ }^{10}$. Ikuspegi horren alde daudenentzat, laguntza-eredu pertsonalizatu batek honako hauek guztiak eskatzen ditu: emandako laguntza jasotako prestazioaren mende ez jartzea; kasu bakoitzaren jarraipenaren eta orientazioaren arduradunei autonomia handia ematea funtsak erabiltzeari eta zerbitzuak esleitzeari dagokienez, edo laguntzak jarraipena izatea behin pertsonak lana aurkitu duenean. Zehazki, pertsonarengan oinarritutako aktibazio-ereduak oinarrizko ezaugarri hauek edukiko lituzke:

- Pertsonen premietara egokitzen diren zerbitzu pertsonalizatuak ematea; eta hainbat programa, zerbitzu eta jardueratan barrena ibiltzea ahalbidetuko duen antolamendu-esparrua sortzea, programa eta zerbitzu horiek kolektibo espezifikoen arabera esleitu beharrean, pertsona bakoitzaren egoeraren, premien eta espektatiben arabera esleitzeko.
- Zuzeneko arretako langileek ekiteko eta erabakitzeko gaitasun handiagoa izatea, pertsona bakoitzarentzako zerbitzu multzoak osatzeari dagokionez ${ }^{11}$. Gainera, horrek esan nahi du onuradunek erabakietan parte hartzeko gaitasun handiagoa eduki behar dutela jasotzen duten laguntza motari dagokionez, eta, ildo horretan, profesionalek, funtsak erabiltzeko eta erabakiak hartzeko ahalmen handiagoa izateaz gain, laguntza-zerbitzuen onuradunek adierazitako iritzi eta premietara egokitzeko gaitasun handiagoa ere erakutsi beharko lukete, jarrera paternalistak edo zorrotzak saihestuz.

- Gizarteratzeko laguntza-zerbitzuak esku hartzeko pakete zabalagoetan integratzea, arreta integralagoa eta holistikoagoa eskaintzeko, premia anizkoitzak dituzten pertsonen kasuan bereziki.

- Zerbitzu-hornitzaile pribatuak erabiltzea, irabaziasmoa duten eta irabazi-asmorik ez duten erakundeak barne, erakunde publikoek eskainitako zerbitzuez gain; nolanahi ere, erakunde publikoak zerbitzuan sartzeko bitartekari izango lirateke.

Aktibazio-programen indibidualizazioaren inguruan garatutako nazioarteko esperientziak (Ben-Galim eta Sachrajda, 2010) hiru alderdi jarri ditu agerian horren eraginkortasunari dagokionez: lan-orientatzaileen trebakuntza eta egokitzapena, kolektibo jakin batzuen (buruko gaixotasunak edo ezgaitasunak dituzten pertsonak, etorkinak, bakarrik dauden amak eta abar) premietara egokitzeko beharra, eta enplegua lortu eta laneratzeari eta lanpostuari eusteko laguntzari arreta berbera eskaintzea, lan-merkatua zertan den ikusita, enplegu bati eustea enplegu hori lortzea bezain zaila delako. Ildo horretan, ezgaituen enplegu lagunduaren arloa asko garatu da, eta gure ingurune hurbilenean ugari dira, halaber, lana dutenei laguntzeko abian jarritako ekimenak. Esperientzia horiek guztiak oso interesgarriak dira, eta, eredu honen esparruan, ahal den neurrian sustatu eta garatu beharko lirateke.

Indibidualizazioaren arabera, zerbitzuak pertsonen premia espezifikoetara egokitzen dira, eta helburu hori guztiz bidezkoa da, baina indibidualizazioari jarraiki, halaber, baldintzazkotasun-irizpideak aplikatzen dira, batetik, gutxieneko errenten prestazioak zehazteko, eta, bestetik laguntzen onuradunei aktibazio-betekizun batzuk bete ditzaten eskatzeko. Dokumentu honetan justifikatu nahi izan dugu zenbateraino eta zer testuingurutan izan daitekeen bidezkoa baldintzazkotasun-irizpide horiek ezartzea. Nolanahi ere, indibidualizazio-arazo horrek baldintzazkotasun-kontzeptuari berari eragiten dio, gizarteratze aktiboko programen onuradunei agindutako baldintzak moldatu behar direlako pertsona bakoitzaren egoera espezifikoaren arabera.

${ }^{11}$ Horretarako funts diskrezionalen erabilera proposatu da (adviser dicretionary funds), orientatzaile pertsonalen eskura daudenak gizarteratzearekin zerikusia duten gastu jakin batzuk estaltzeko.
${ }_{9}^{9}$ Gizartean gure ingurune hurbilenean garatu den lagun-egite kontzeptuarekin bat etorriz.

${ }_{10}$ Pertsonarengan oinarritutako aktibazio-kontzeptua pertsonarengan oinarritutako plangintzarekin du zerikusia, desgaituen arretaren eremuan asko erabili dena. FEAPS elkartearen arabera, pertsonarengan oinarritutako plangintza lankidetza-prozesu bat da, eta, bereziki, bizi-kalitatea hobetzeko behar dituzten laguntza eta zerbitzuak jarri nahi ditu pertsonen eskura, haien esperientzia eta balioetatik abiatuta. Bizitza planifikatzeko estrategia multzoa da, pertsonaren eta pertsonaren gertukoen iritzian eta erabakietan oinarritzen dena. Berez desgaituen kolektiboen eskutik sortu bazen ere, lanmetodologia baliagarria da gizarte-bazterkeriako egoeran edo egoera horretan erortzeko arriskuan dagoen edozein pertsonarentzat. 


\subsubsection{Enplegutik urrunen dauden egoerak}

Baldintzazkotasun indibidualizatuko irizpide batzuk muga jakin batzuen barruan aplikatzeak zerikusia $\mathrm{du}$, halaber, bazterkeria-egoera larrienean dauden pertsonen egoerarekin, hain zuzen ere lan-merkatutik urrunen egonik oso enplegagarritasun-maila txikiak dituzten pertsonen egoerarekin.

Izan ere, ez dugu ahaztu behar Lanbide Euskal Enplegu Zerbitzura diru-sarrerak bermatzeko prestazioen eske jotzen dutenetako asko -pentsiodunak alde batera utzita, lan-arloko eskakizunik bete beharrik ez dutenak- ez daudela lanpostu bat lotzeko moduan, eta litekeena dela denbora askoan horrela jarraitzea. Ikuspegi horretatik, muga fisiko, psikiko edota sozialak dituztelako edo guraso-erantzukizunak dituztelako (bakarrik egonik oso haur txikiak dituzten amen kasuan, zehazki) ${ }^{12}$ enplegu bat lortzeko moduan ez dauden pertsonei lan-baldintzarik gabeko irizpide bat aplikatu beharko litzaieke, aktibazio-erregimen zorrotzen alde dauden herrialdeek ere egiten duten bezala. Beste zenbaitetan, neurri txikiagoan bada ere, laneratzeko zailtasunek bestelako harreman- eta funtzio-zailtasunekin dute zerikusia, eta Gizarte Zerbitzuek horien gaineko ardura hartu behar dute, ezinbestean. Kasu horietan, gizarteratzeko zailtasunak zailtasun eta gabezia sorta zabal baten zati bat baino ez dira, edo bestela, horien ondorio, eta Enplegu Zerbitzuek, Gizarte Zerbitzuek eta gainerako ongizate-sistemek elkarlanean jardun beharko dute, ezinbestean. Gainera, sistema egoki batzuk ezarri beharko dira, gabezia horietako bakoitzak pertsonaren egoeran zenbaterainoko garrantzia duten neurtzeko eta esku-hartzearen ardura hartuko duen zerbitzua zehazteko.

Edozein kasutan, egoera horretan edozein elkarrekikotasun-eskari gehiegizkotzat jo daiteke, baita abusuzkotzat ere, bereziki ezarritako baldintzek enplegua lortzeari lehentasuna ematen badiote. Kasu horietan, eta gizarteratze-kontzeptuaren esanahiari dagokionez aldez aurretik aipatu diren faktoreak kontuan hartuta, onartu beharra dago kasu horietan laneratzea bigarren maila batean geratzen dela, eta honako arlo hauetan esku hartzeari lehentasuna eman behar zaiola: funtzionamendu psikosozialeko oinarrizko maila batzuk berreskuratzea, familiaedo gizarte-harremanetan sor daitezkeen arazoak konpontzea, etxebizitza- edo ostatu-arazoak eta abar.
Ikuspegi horretatik abiatuta, aktibazio-irizpide zorrotzagoak aplikatu direnean ere kontuan hartu da baldintzazkotasun-printzipioaren aplikazio zorrotzegi bat oso kaltegarri gerta daitekeela egoera bereziki kalteberenean dauden pertsonentzat. Egoera horien aurrean, bi esku-hartze ildo susta daitezke. Lehenik, Deanen proposamenekin bat etorriz (2003), lanbetebeharren aldean bizi-premia indibidualei lehentasuna emango dien ikuspegia sustatu behar da (life first approach). Aktibazioaren paradigmara hobeto moldatuko den lan-ildo errealistago batek, ordea, estrategia bikoitza aplikatzea ekarriko luke berekin:

- Batetik, aldez aurretik aipatutakoaren haritik, baldintzazkotasun-irizpide indibidualizatuak aplikatu beharko lirateke, pertsona bakoitzaren unean uneko egoera aintzat hartuko luketenak, oso egoera desberdinetan eta oso arazo desberdinak dituzten pertsonei baldintza berberak jarri gabe.

- Bestetik, aktibazio-programen ardura eta jarduna laneratzeko zailtasun gehien edo lan-merkatutik urrunen dauden kolektiboetara bideratu beharko lirateke. Ildo horretan, Peckek eta Theodorek (2000) agerian utzi dute enplegagarritasunaren ohiko ikuspegiaren arabera "enpleguak pertsona enplegagarrienei ematea” sustatzen dela, enplegagarritasunaren hobekuntzak ez dakarrelako berekin enplegu-eskari erantsia igotzea. Ikuspegi horri jarraiki, egile horiek aldarrikatzen duten aktibazio-ikuspegiaren arabera, lan-aukerak birbanatzerakoan lehentasuna eman beharko litzaieke desabantailazko edo bazterkeriako egoera larrienean dauden taldeei, baliabideak eta energiak laneratzeko oztopo gehien dituzten enplegu-eskatzaileen eskura jarriz. Hortaz, lan-merkatuan indarrean dauden desberdintasunereduak iraunarazteko eta lan-merkatutik gertuen daudenak laneratzeko joera duen enplegagarritasun-ikusmoldearen aldean, Theodorek eta Peckek aktibazio-programen ikuspegi birbanatzailea proposatzen dute, enplegua lortzeko aukera gutxien dituzten pertsonei lehentasuna emanez eta lan-merkatuaren barruan desberdintasunak mugatuz, diskriminazioaren aurkako, hezkuntzako eta kalitatezko prestakuntzako neurrien eta prestazio egokien bitartez, eta lan-eskubideak hedatuz. 


\section{Aipatutako bibliografia}

ARRIBA, A.; eta PÉREZ ERANSUS, B. (2007): “La última red de protección social en España: prestaciones asistenciales y su activación", Política y Sociedad, 44. bol., 2. zenb. 115-133 or. [khttp:// revistas.ucm.es/index.php/POSO/article/view/ POSO0707230115A〉].

BEN-GALIM, D.; eta SACHRAJDA, A. (ed.) [2010]: Now It's Personal: Learning from Welfare to Work Approaches around the World, Londres, Institute for Public Policy Research [khttp:// www.researchonline.org.uk/sds/search/ download.do;jsessionid $=97495 \mathrm{E} 74 \mathrm{BB} 1 \mathrm{EA6677E}$ 16C70614F4530A?ref $=$ B16954'].

DEAN, H. (2003): "Re-conceptualising welfare-to-work for people with multiple problems and needs", Journal of Social Policy, 32. bol., 3 zenb., 441459 or. ['http://eprints.lse.ac.uk/338/>].

GORTE NAGUSIAK (1978): “Constitución española”, Boletín Oficial del Estado, 311. zenb., 29-12-1978, 29.313-29.424 or. [<http://www.boe.es/buscar/ doc.php?id=BOE-A-1978-31229'].

GORZ, A. (1995): Metamorfosis del trabajo, búsqueda del sentido: crítica de la razón económica, Madrid, Sistema.

HAINBAT EGILE (2010): Joera sozialak eta gizarteratzea / Tendencias sociales e inclusión social, Bilbo, Sartu Federazioa [<http://www.sartu.org/files/ JoerasozialakAZK.pdf〉, 〈http://www.sartu.org/ files/TendenciasSocialesDEF.pdf $\rangle$.

JAURLARITZAREN LEHENDAKARITZA (2008): 18/2008 Legea, abenduaren 23koa, Gizarteratzeko eta Diru Sarrerak Bermatzekoa, Euskal Herriko Agintaritzaren Aldizkaria, 250 zenb., Il.alezatia, 2008-12-31, 32.729-32.804 or. [khttp://www. euskadi.net/bopv2/datos/2008/12/0807235a. pdf〉].
MCNEIL, C. (2010): Now It's Personal? The New Landscape of Welfare-to-work, Londres, Institute for Public Policy Research [<http://www.ippr.org/ publication/55/1797/now-its-personal-the-newlandscape-of-welfare-to-work>].

MCQUAID, R. W.; eta LINDSAY, C. (2005): "The concept of employability", Urban Studies, 42. bol., 2. zenb., 197-219 or. [<http://eprints.whiterose. ac.uk/50721/1/Concept_of_Employability_ FINAL.pdf >].

MEAD, L. M. et al. (1997): From Welfare to Work. Lessons from America, saila: Choice in Welfare, Londres, Institute of Economic Affairs.

MOREIRA, A. (2008): The Activation Dilemma. Reconciling the Fairness and Effectiveness of Minimum Income Schemes in Europe, Bristol, Policy Press.

MORENO, L.; eta SERRANO PASCUAL, A. (2009): “Modelo social europeo y políticas sociales: una evaluación formativa institucional", Gestión y Análisis de Políticas Públicas, 2. zenb., 11-32 or. [rhttp://revistasonline.inap.es/index. php?journal $=$ GAPP $\&$ page $=$ article $\&$ op $=$ view $\& p$ ath[]=419>].

- (2007): “Europeización del bienestar y activación”, Política y Sociedad, 44. bol., 2. zenb., 31-44 or. [khttp://revistas.ucm.es/cps/11308001/ articulos/POSO0707230031A.pdfs].

PALACIOS, A.; eta BARIFFI, F. (2007): La discapacidad como una cuestión de derechos humanos. Una aproximación a la Convención Internacional sobre los Derechos de las Personas con Discapacidad, saila: Telefónica Accesible, 4. zenb., Madril, Ediciones Cinca [<http://info. telefonica.es/ext/accesible/html/home/ pdf/0004_discapacidad.pdf)]. 
PECK, J.; eta THEODORE, N. (2000): “Beyond 'employability”, Cambridge Journal of Economics, 24. bol., 6. zenb., 729-749 or.

PÉREZ ERANSUS, B. (2009): “La activación como criterio político para la intervención social en el ámbito de la exclusión”, in: Actuar ante la exclusión. Análisis, políticas y herramientas para la inclusión social, bilduma: Estudios, 29. zenb., Madril, Cáritas Española; Madril, Fundación FOESSA.

- (2006): “Rentas mínimas y políticas de activación”, Documentación Social, 143. zenb., 77-92 or. [<http://tinyurl.com/7hw58j6>].

- (2005): Políticas de activación y rentas mínimas, saila Estudios, 11. zenb., Madril, Cáritas.

RENZAGLIA, A. et al. (2003): "Promoting a lifetime of inclusion", Focus on Autism and Other Developmental Disabilities, 18. bol., 3. zenb., $140-149$ or. [khttp:// www.worksupport.com/documents/proed promotingLifetimelnclusion.pdf $\rangle]$.

RETOLAZA, J. L. (2003): “La validez de las políticas activas de inserción / Gizarteratze politiken baliagarritasuna", in Hilero Eguneratuz, 31. zenb., 1. or.
SIIS DOKUMENTAZIO ETA IKERKETA ZENTROA (2011): Activación y derecho a la inclusión en el marco de las políticas de empleo y de garantía de ingresos en la CAPV, Gasteiz, Eusko Jaurlaritza [khttp://www.siis.net/documentos/ ficha/197806.pdf>].

TERGEIST, P.; eta GRUBB, D. (2006): Activation strategies and the performance of employment services in Germany, The Netherlands and the United Kingdom, Paris, Ekonomia Lankidetza eta Garapenerako Antolakundea [khttp://www. oecd.org/dataoecd/32/22/37848464.pdfı].

TOHARIA, L. et al. (2007): Empleo e inclusión social, Madril, Lan eta Gizarte Gaietako Ministeritza.

WHITE, S. (2000): "Social rights and the social contract. Political theory and the new welfare politics", British Journal of Political Science, 30. bol., 3. zenb., 507-532 or. [shttp://www.brynmawr. edu/socialwork/GSSW/schram/whitemead.pdf〉].

- (1999): "Rights and responsibilities: A social democratic perspective”, Political Quarterly, 70. bol., S1. zenb., 166-179 or. 